\title{
Role of Serosal TRPV4-Constituted SOCE Mechanism in Secretagogues-Stimulated Intestinal Epithelial Anion Secretion
}

\author{
Yinghui Cui ${ }^{1}$, Fenglan $\mathrm{Chu}^{2}$, Kai Yin ${ }^{2}$, Xiongying Chen ${ }^{1}$, Hanxing Wan ${ }^{1}$, Gang Luo ${ }^{2}$, \\ Hui Dong ${ }^{1,2 *}$ and Feng $\mathrm{Xu}^{1 *}$
}

${ }^{1}$ Department of Pediatric Intensive Care Unit, Children's Hospital of Chongqing Medical University; National Clinical Research Center for Child Health and Disorders; Ministry of Education Key Laboratory of Child Development and Disorders; Chongqing Key Laboratory of Pediatrics, Chongqing, China, ${ }^{2}$ Department of Gastroenterology, Xinqiao Hospital, Army Medical University,

Chongqing, China

OPEN ACCESS

Edited by:

Salvatore Salomone,

University of Catania, Italy

Reviewed by:

James S. K. Sham,

Johns Hopkins University,

United States

Yasutada Akiba,

University of California, Los Angeles,

United States

*Correspondence:

Hui Dong

dhxq@tmmu.edu.cn

Feng $X_{U}$

xufeng9899@163.com

Specialty section:

This article was submitted to

Experimental Pharmacology and Drug

Discovery,

a section of the journa

Frontiers in Pharmacology

Received: 23 March 2021 Accepted: 24 June 2021

Published: 14 July 2021

Citation:

Cui Y, Chu F, Yin K, Chen X, Wan H, Luo G, Dong H and Xu F (2021) Role of

Serosal TRPV4-Constituted SOCE

Mechanism in Secretagogues-

Stimulated Intestinal Epithelial

Anion Secretion.

Front. Pharmacol. 12:684538.

doi: 10.3389/fphar.2021.684538
As little is known about the role of calcium $\left(\mathrm{Ca}^{2+}\right)$ signaling mediating the small intestinal epithelial anion secretion, we aimed to study its regulatory role in secretagogue-stimulated duodenal anion secretion and the underlying molecular mechanisms. Therefore, intestinal anion secretion from native mouse duodenal epithelia was examined with Ussing chambers to monitor $\mathrm{PGE}_{2^{-}}, 5-\mathrm{HT}$-, and CCh-induced short-circuit currents $\left(I_{s c}\right)$. PGE 2 $(10 \mu \mathrm{M})$ and $5-\mathrm{HT}(10 \mu \mathrm{M})$ induced mouse duodenal $I_{s c}$, markedly attenuated by serosal $\mathrm{Ca}^{2+}$-free solution and selective blockers of store-operated $\mathrm{Ca}^{2+}$ channels on the serosal side of the duodenum. Furthermore, $\mathrm{PGE}_{2^{-}}$and $5-\mathrm{HT}$-induced duodenal $I_{S C}$ was also inhibited by ER $\mathrm{Ca}^{2+}$ chelator TPEN. However, dantrolene, a selective blocker of ryanodine receptors, inhibited $\mathrm{PGE}_{2}$-induced duodenal $I_{s c}$, while $\mathrm{LiCl}$, an inhibitor of $\mathrm{IP}_{3}$ production, inhibited 5-HT-induced $I_{s c}$. Moreover, duodenal $I_{s c}$ response to the serosal applications of both $\mathrm{PGE}_{2}$ and $5-\mathrm{HT}$ was significantly attenuated in transient receptor potential vanilloid 4 (TRPV4) knockout mice. Finally, mucosal application of carbachol $(100 \mu \mathrm{M})$ also induced duodenal $I_{s c}$ via selective activation of muscarinic receptors, which was significantly inhibited in serosal $\mathrm{Ca}^{2+}$-free solution but neither in mucosal $\mathrm{Ca}^{2+}$-free solution nor by nifedipine. Therefore, the serosal TRPV4-constituted SOCE mechanism is likely universal for the most common and important secretagogues-induced and $\mathrm{Ca}^{2+}$-dependent intestinal anion secretion. These findings will enhance our knowledge about gastrointestinal (G.I.) epithelial physiology and the associated G.I. diseases, such as diarrhea and constipation.

Keywords: calcium signaling, PGE $_{2}, 5-H T$, SOCE, CRAC, TRPV4, CCH

\section{INTRODUCTION}

Intestinal epithelial ion secretion is a critical physiological process in the human gastrointestinal (G.I.) tract. Since water follows ion movement across osmotic gradients, which is primarily generated by chloride ion $\left(\mathrm{Cl}^{-}\right)$and bicarbonate $\left(\mathrm{HCO}_{3}{ }^{-}\right)$secretion (Barrett and Keely, 2000; Kiela and Ghishan, 2009), the clarification of these processes is essential to delineate the pathophysiology of various diarrheal diseases. The $\mathrm{Cl}^{-}$and $\mathrm{HCO}_{3}{ }^{-}$secretions are under the 
control of several secretagogues in the G.I. system. Like prostaglandin $\mathrm{E}_{2}\left(\mathrm{PGE}_{2}\right)$, is a potent chloride secretagogue likely to be active under physiological and pathophysiological circumstances (Weymer et al., 1985; Rajagopal et al., 2014); meantime, $\mathrm{PGE}_{2}$ stimulates duodenal bicarbonate secretion to protect the mucosal epithelium against acid-induced injury in various species (Takeuchi and Amagase, 2018). Furthermore, 5-hydroxytryptamine (5-HT) is also an essential secretagogue of $\mathrm{Cl}^{-}$and $\mathrm{HCO}_{3}^{-}$secretion, and it is released by enterochromaffin (E.C.) cells situated in the intestine epithelium (Brown, 1995). Besides, acetylcholine (ACh) is a primary neurotransmitter in activating intestinal anion secretion.

These secretagogues described above mediate epithelial ion transports via three major second messengers: cAMP, cGMP, and $\mathrm{Ca}^{2+}$ (Murek et al., 2010). Among these messengers, the physiological roles and molecular mechanisms of cAMP- and cGMP-dependent regulation of intestinal ion transports have been well elucidated (Rao et al., 1984; Tuo et al., 2009), while those mediated via calcium signaling remain relatively poorly understood.

It is commonly believed that in non-excitable cells, secretagogues evoke calcium signaling through two necessary processes: the release of $\mathrm{Ca}^{2+}$ from intracellular stores, then an enhanced extracellular $\mathrm{Ca}^{2+}$ entry (Putney, 2007), which was called capacitative or store-operated $\mathrm{Ca}^{2+}$ channels (SOCs) classically. The intracellular store in the endoplasmic reticulum (E.R.) from which $\mathrm{Ca}^{2+}$ is released in two main ways, which is via the ryanodine receptor (RyR) or the inositol trisphosphate receptor $\left(\mathrm{IP}_{3} \mathrm{R}\right)$ (MacMillan et al., 2005). These $\mathrm{Ca}^{2+}$ release-activated $\mathrm{Ca}^{2+}$ channels (CRAC) were first described in mast cells and Jurkat lymphocytes (Hoth and Penner, 1992; Hoth and Penner, 1993). However, detailed underlying mechanisms that secretagogues mediated cytosolic $\mathrm{Ca}^{2+}$ signaling in duodenal anion secretion still need to elucidate (Xie et al., 2014). In addition, while molecular components of SOCE are well defined in immune cells, their molecular identification is still elusive in intestinal epithelial cells.

We previously demonstrated that carbachol (CCh), a stable chemical analog of neurotransmitter $\mathrm{ACh}$, triggered $\mathrm{IP}_{3} \mathrm{R} / \mathrm{ER}$ $\mathrm{Ca}^{2+}$ release, but caffeine triggered $\mathrm{RyR} / \mathrm{ER} \mathrm{Ca}^{2+}$ release, both of which stimulated serosal store-operated $\mathrm{Ca}^{2+}$ entry (SOCE) mechanism and eventually induced $\mathrm{Ca}^{2+}$-dependent duodenal anion secretion (Yang et al., 2018; Zhang et al., 2019; Zhang et al., 2021) However, it is currently unclear: 1) whether $\left[\mathrm{Ca}^{2+}\right]_{\text {cyt }}$ is also a critical cell signaling for other most common and important secretagogues, such as $\mathrm{PGE}_{2}$ and 5HT; 2) if serosal SOCE is a universal mechanism for $\mathrm{Ca}^{2+}$ dependent duodenal anion secretion; 3 ) if so, what molecular components of the SOCE are involved in this process; and 4) if $\mathrm{CCh}$ evokes a $\mathrm{Ca}^{2+}$-dependent anion secretion when applied from the mucosal side of the duodenum, although it is well known to stimulate it from the serosal side. Therefore, we aimed to investigate these important issues using native duodenal epithelial tissues in mice as a follow-up study.

\section{MATERIALS AND METHODS}

\section{Animals and Cells}

All experiments were adopted with adult male Harlan C-57BL/6 mice (6-8 weeks old; 18-22 g; Chongqing Tengxin Biotechnology Co. Ltd., Chongqing, China) and transient receptor potential vanilloid 4 (TPPV4) deficient (TRPV4 KO) mice which generated from C-57BL/6 mice (6-12 weeks old; 20-25 g; Cyagen bioscience, China). Animal care and experiments conformed with the guidance of the Animal Ethical Committee of the University and were approved by the University Committee on Investigations Involving Animal Subjects. According to the ARRIVE guidelines (Kilkenny et al., 2010), the mice were bred and housed in a standard animal care room at an ambient temperature of $20^{\circ} \mathrm{C}$ and air humidity of $50-55 \%$ on a $12 \mathrm{~h}$ : $12 \mathrm{~h}$ light-dark cycle with free access to water and food pellets until the time of experiments. Before each experiment, mice's food and water were deprived for at least $1 \mathrm{~h}$. Mice were sacrificed by cervical dislocation under narcosis with $100 \% \mathrm{CO}_{2}$. Animals were assigned randomly to different experimental groups of all studies. Data collection and evaluation of all experiments performed blindly, and the experimenters were unaware of group treatments.

IEC-6, a small intestinal epithelial cell line of rat origin (Thomas and Oates, 2002), was obtained from the American Type Culture Collection (ATCC, Rockville, MD, United States) and routinely cultured in fresh Dulbecco's modified eagle's medium (DMEM) supplemented with 10\% Fetal bovine serum (FBS), glutamine and penicillin/streptomycin every 2 days. After the cells had grown well for experiments, they were replated onto $12 \mathrm{~mm}$ round coverslips (Warner Instruments Inc., Hamden, CT, United States) and incubated for at least $24 \mathrm{~h}$ before use for $\left[\mathrm{Ca}^{2+}\right]_{\text {cyt }}$ measurement.

\section{Solutions}

Solutions to the mucosal side in the Ussing chamber experiments contained the following: $115 \mathrm{mM} \mathrm{NaCl}, 25 \mathrm{mM}$ sodium-Dgluconate, $5.2 \mathrm{mM}$ potassium-D-gluconate, $1.2 \mathrm{mM} \mathrm{CaCl}_{2}$, $1.2 \mathrm{mM} \mathrm{MgCl}_{2}$, and $10 \mathrm{mM} \mathrm{D}$-mannitol at $\mathrm{pH} 7.4$ when gassed with Oxygen $\left(100 \% \mathrm{O}_{2}\right)$ at $37^{\circ} \mathrm{C}$. The serosal solution contained the following: $115 \mathrm{mM} \mathrm{NaCl}, 25 \mathrm{mM} \mathrm{NaHCO}_{3}$, $2.2 \mathrm{mM} \mathrm{K}_{2} \mathrm{HPO}_{4}, 1.2 \mathrm{mM} \mathrm{CaCl}_{2}, 1.2 \mathrm{mM} \mathrm{MgCl}_{2}, 0.8 \mathrm{mM}$ $\mathrm{KH}_{2} \mathrm{PO}_{4}, 10 \mathrm{mM} \mathrm{D}$-glucose, and this solution was gassed with carbogen $\left(5 \% \mathrm{CO}_{2}\right.$ and $\left.95 \% \mathrm{O}_{2}, \mathrm{v} / \mathrm{v}\right)$ at $37^{\circ} \mathrm{C}$ and had a $\mathrm{pH} 7.4$. For the $\mathrm{Ca}^{2+}$-free experiments, $\mathrm{Ca}^{2+}$ was omitted, and EGTA $(0.5 \mathrm{mM})$ was added in both mucosal and serosal solutions to prevent potential $\mathrm{Ca}^{2+}$ contamination. The physiological salt solution (PSS) used in digital $\mathrm{Ca}^{2+}$ measurement contained the following: $140 \mathrm{mM} \mathrm{NaCl}, 5 \mathrm{mM} \mathrm{KCl}, 2 \mathrm{mM} \mathrm{CaCl} 2,10 \mathrm{mM}$ HEPES, and $10 \mathrm{mM}$ glucose ( $\mathrm{pH} 7.4)$. For the $\mathrm{Ca}^{2+}$-free PSS solution, $\mathrm{Ca}^{2+}$ was omitted, but $0.5-\mathrm{mM}$ EGTA was added. The osmolalities for all solutions were $300 \mathrm{mOsmol} \mathrm{kg}{ }^{-1}$ of $\mathrm{H}_{2} \mathrm{O}$.

\section{Tissue Preparations}

Following euthanasia, the mice's abdomen was opened by a midline incision. Next, we dissected the proximal duodenum 
$4 \mathrm{~cm}$ from the pylorus carefully and immediately but not pulled to avoid damaging the epithelium. Afterward, the duodenum section was incubated in ice-cold iso-osmolar mannitol $(300 \mathrm{mM})$ and indomethacin $(1 \mu \mathrm{M})$ solution $10 \mathrm{~min}$ before seromuscular stripping to inhibit possible endogenous $\mathrm{PGE}_{2}$, which is resulting from mucosal injury during experiments, to avoid affecting the basal $I_{s c}$. Finally, the section is opened longitudinally, with the mesenteric attachment remnant, seromusculature stripped, and divided into four segments. The segment, which is likely to undergo less excision damage, will be situated in the chambers' aperture (window area, $0.1 \mathrm{~cm}^{2}$ ).

\section{Ussing Chamber Experiments}

Segments were fixed in a modified Ussing chamber bathed with a volume of $3 \mathrm{ml}$ on each side of the mucosa preparation at $37^{\circ} \mathrm{C}$ and short-circuited by a computer-controlled voltage-clamp device (Voltage-Current Clamp, VCC MC6; Physiologic Instruments, San Diego, CA, United States) under continuous short-circuited conditions. An automatic voltage-clamp measured the transepithelial short-circuit currents $\left(I_{s c}\right)$, while $\mu \mathrm{A}$ was used for the original recordings, and $\mu \mathrm{A} \mathrm{cm}^{-2}$ was used for summary data. After 10-15 min of measurements for basal parameters, various agonists or antagonists were added to one side or both sides for 10-20 min, followed by $\mathrm{PGE}_{2}, 5-\mathrm{HT}$, and carbachol.

\section{Calcium Image Experiments}

$\left[\mathrm{Ca}^{2+}\right]_{\text {cyt }}$ measurement experiments were performed as previously described (Zhang et al., 2019). ICE-6 Cells grown on coverslips were loaded with $5 \mu \mathrm{M}$ Fura-2/AM in PSS, described above, at room temperature $\left(22-25^{\circ} \mathrm{C}\right)$ for $50 \mathrm{~min}$ and then washed for $30 \mathrm{~min}$. After that, the coverslips with epithelial cells were mounted in a perfusion chamber on a Nikon microscope stage (Nikon Corp., Tokyo, Japan). The ratio of Fura-2/AM fluorescence with excitation at 340 or $380 \mathrm{~nm}$ (F340/380) was followed over time and captured using an intensified charge-coupled device camera (ICCD200) and a MetaFluor imaging system (Universal Imaging Corp., Downingtown, PA, United States).

\section{Materials}

Prostaglandin $\mathrm{E}_{2}$, Serotonin hydrochloride(5-HT), SKF-96365, TPEN (N, N, $\mathrm{N}^{\prime}, \quad \mathrm{N}^{\prime}$ - tetrakis (2-pyridylmethyl) ethylenediamine), GSK-7975A, ouabain, HC067047, and GSK1016790A were purchased from MedChemExpress (MCE; Monmouth Junction, NJ, United States). Sigma (Saint Louis, MO, United States) supplied carbamylcholine chloride (CCh), nifedipine, gadolinium chloride, and cyclopiazonic acid (CPA). Tocris Bioscience (Ellisville, MO, United States) supplied 2Aminoethoxydiphenyl borate (2-APB), while APExBIO Technology LLC (Houston, TX, United States) provided dantrolene. Fura-2 was purchased from Invitrogen (UT, United States), meantime DMEM and FBS were obtained from Hyclone (Logan, UT, United States). Trypsin and penicillin/ streptomycin were purchased from Gibco (CA, United States). The other chemicals were obtained from BBI Life Science (Shanghai, China).
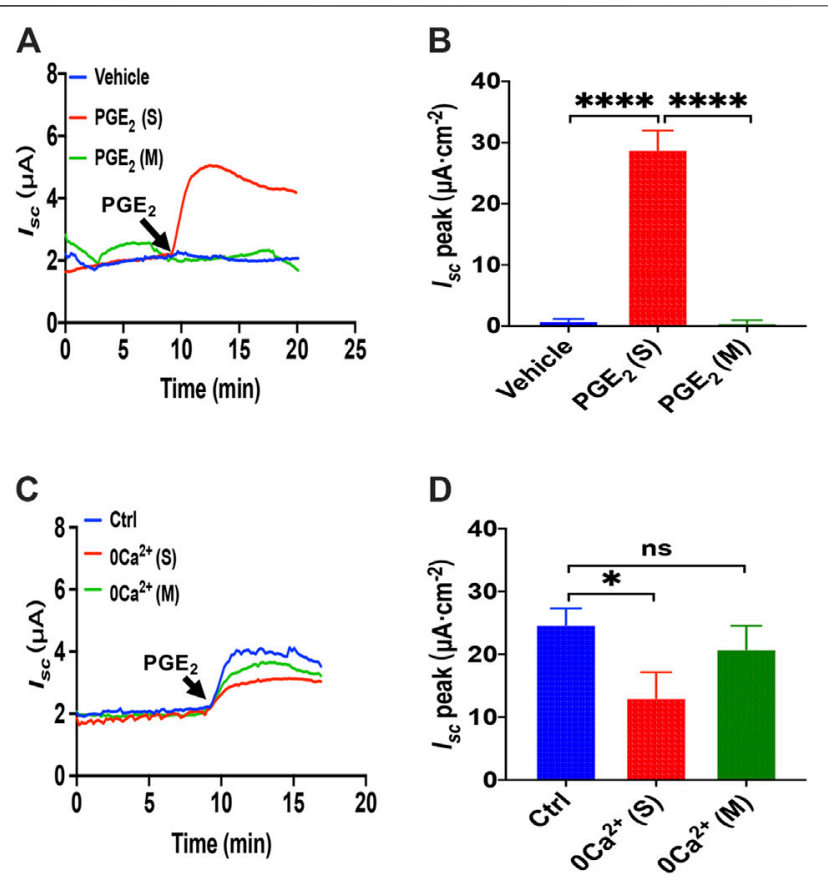

FIGURE 1 | $P E_{2}$ induced $\mathrm{Ca}^{2+}$-dependent small intestine epithelial anion secretion. (A) Time courses of PGE $2(10 \mu \mathrm{M})$-evoked $I_{s c}$ or vehicle (DMSO) when applied to the serosal (s) or mucosal (m) side of mice duodenal mucosal tissues $(n \geq 6)$. (B) When added to the serosal or mucosal side, vehicle or $\mathrm{PGE}_{2}$-stimulated $I_{s c}$ peak $(n=6)$. (C) Time courses of $\mathrm{PGE}_{2}$-evoked $I_{s c}$ after extracellular $\mathrm{Ca}^{2+}$ omission $\left(0 \mathrm{Ca}^{2+}\right)$ from each side in duodenal mucosal tissues. (D) $\mathrm{PGE}_{2}$-stimulated $I_{s c}$ peak after $\mathrm{Ca}^{2+}$ omission from each side $(n \geq 6)$. Ctrl represents as the control in which normal extracellular $\mathrm{Ca}^{2+}$ was on both sides. Results are presented as mean \pm SE. ${ }^{\star} p<0.05,{ }^{\star \star \star \star} p<$ 0.0001 , significantly different from the corresponding control by one-way ANOVA followed by Dunnett's post-test.

\section{Data and Statistical Analysis}

Data and statistical analysis yield to the recommendations of Frontiers in Pharmacology. All results are given as means \pm standard error of the mean number $(n)$ of investigated tissues. Net peak of duodenal $I_{s c}$ refers to drug-stimulated maximal peak minus basal level. The statistical significance of differences in experimental groups' means was determined by using Student's unpaired, two-tailed t-test or one-way ANOVA followed by Dunnett's post-test. Post hoc tests were run if $\mathrm{F}$ achieved $p<$ 0.05 (GraphPad Prism 8.0), and there was no significant variance in inhomogeneity. A probability $P$-value $<0.05$ was considered statistically significant.

\section{RESULTS}

\section{Prostaglandin $\mathrm{E}_{2}$ Induced $\mathrm{Ca}^{2+}$-Dependent Epithelial Anion Secretion in Duodenum}

Since $\mathrm{PGE}_{2}$ is one of the most common and important secretagogues, we conducted Ussing chamber experiments to test its effect on $\mathrm{Ca}^{2+}$-dependent duodenal epithelial anion transports. Because the duodenal epithelium is polarized, with the mucosal side and the serosal side, we tested which side was 

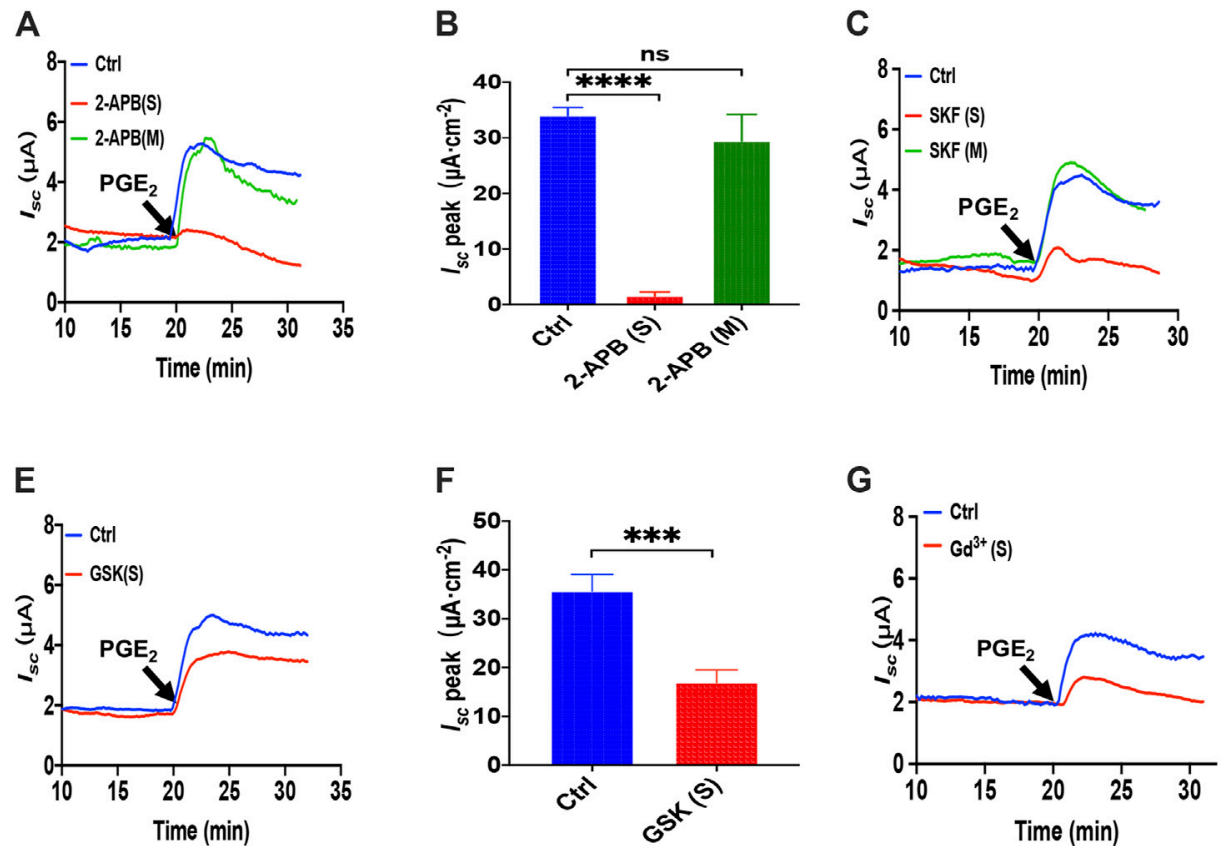
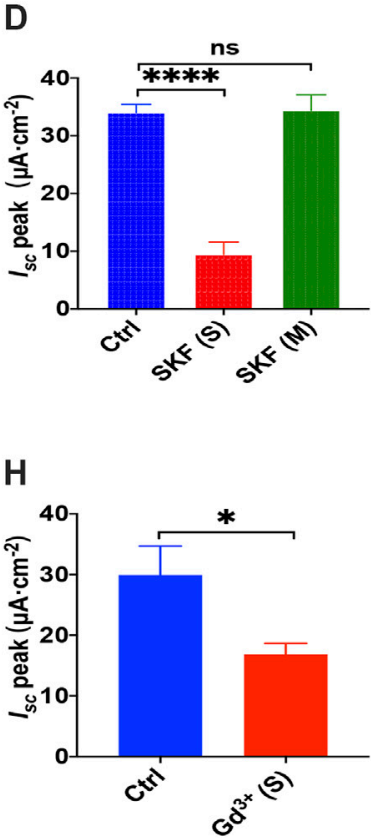

FIGURE 2 | $\mathrm{PGE}_{2}$ induced $\mathrm{Ca}^{2+}$-dependent ion secretion by serosal SOCE mechanism in mice duodenum. (A) Time course of PGE 2 (10 $\left.\mu \mathrm{M}\right)$-evoked $I_{\text {sc }}$ after

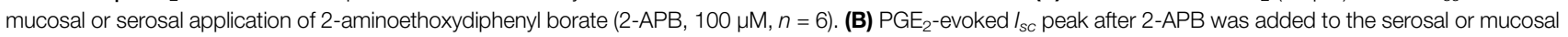

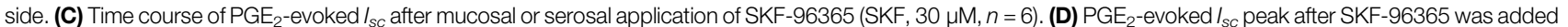
to the serosal or mucosal side. (E) Time course of PGE ${ }_{2}$-evoked duodenal $I_{S C}$ after serosal application of GSK-7975A (GSK, $100 \mu M$, $n=6$ ). (F) PGE ${ }_{2}$-evoked

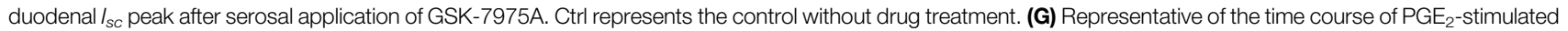
duodenal $I_{s c}$ after serosal addition of $\mathrm{GdCl}_{3}\left(\mathrm{Gd}^{3+}, 30 \mu \mathrm{M}, n=6\right)$. (F) Summary of the effect of $\mathrm{GdCl}_{3}$ on $\mathrm{PGE}_{2}$-stimulated duodenal $I_{s c}$ peak after serosal addition. Ctrl represents the control without drug treatment. Results are presented as mean \pm SE. NS, no significant differences, ${ }^{\star} p<0.05$, ${ }^{\star \star \star} p<0.001$, ${ }^{\star \star \star \star} p<0.0001$ vs. corresponding control by Student's unpaired, two-tailed t-test or one-way ANOVA followed Dunnett's post-test.

acted by $\mathrm{PGE}_{2}$. The addition of $\mathrm{PGE}_{2}(10 \mu \mathrm{M})$ in the serosal induced a transient high $I_{s c}$ peak with a sustained phase following (Figure 1A). However, $\mathrm{PGE}_{2}$ and vehicle (DMSO) mucosal application did not affect the duodenal $I_{s c}$ (Figures 1A,B). Therefore, $\mathrm{PGE}_{2}$ acts on the serosal side of the duodenum exclusively.

To examine whether extracellular $\mathrm{Ca}^{2+}$ is vital for $\mathrm{PGE}_{2}-$ evoked anion secretion, we omitted extracellular $\mathrm{Ca}^{2+}$ on the serosal or mucosal sides of the Ussing chamber. We found that calcium omission of the serosal side weakened the $\mathrm{PGE}_{2}$-evoked $I_{s c}$ peak but not the mucosal side (Figures 1A,B). Therefore, the presence of $\mathrm{Ca}^{2+}$ in the serosal side is critical for $\mathrm{PGE}_{2}$-induced duodenal $I_{s c}$.

\section{Prostaglandin $\mathrm{E}_{2}$ Induced $\mathrm{Ca}^{2+}$-Dependent Ion Secretion by Serosal Store-Operated $\mathrm{Ca}^{2+}$ Entry Mechanism}

To examine if the SOCE mechanism was involved in $\mathrm{PGE}_{2}$ mediated anion transports, we adapted four inhibitors with different chemical structures to block SOCE. Considering 2$\mathrm{APB}$ is a SOCE and an inconsistent $\mathrm{IP}_{3} \mathrm{R}$ inhibitor (Bootman et al., 2002), we first applied 2-APB to test. We found that 2-APB $(100 \mu \mathrm{M})$ had no effect on $\mathrm{PGE}_{2}$-stimulated duodenal $I_{s c}$ after mucosal addition while adding in the serosal side significantly attenuated the duodenal $I_{s c}$ (Figures 2A,B). Like 2-APB, SKF96365, a selective SOCE blocker added in the serosal side but not the mucosal side, also significantly suppressed the duodenal $I_{s c}$ (Figures 2C,D).

Since GSK-7975A is a specific blocker of the CRAC channel (Molnar et al., 2016), we tested if the CRAC channel is SOCE in the duodenal epithelium utilizing it. As shown in Figures 2E,F, GSK-7975A $(100 \mu \mathrm{M})$ markedly reduced $\mathrm{PGE}_{2}$-stimulated duodenal $I_{s c}$. Furthermore, considering $\mathrm{Gd}^{3+}$ has been the most widely employed tool for blocking SOCE and CRAC/ Orai channel (Bird et al., 2008; Sataloff et al., 2017), we added $\mathrm{GdCl}_{3}(30 \mu \mathrm{M})$ in the serosal side significantly reduced $\mathrm{PGE}_{2}-$ stimulated duodenal $I_{s c}$ (Figures 2G,H). Therefore, $\mathrm{PGE}_{2}$ induced $\mathrm{Ca}^{2+}$-dependent ion secretion by acting on the serosal SOCE mechanism and probably CRAC channels in the duodenal epithelium.

\section{$E R \mathrm{Ca}^{2+}$ Store and Ryanodine Receptors in $\mathrm{PGE}_{2}$-Induced Intestinal Ion Transports}

As is know that $\mathrm{N}, \mathrm{N}, \mathrm{N}^{\prime}, \mathrm{N}^{\prime}$-tetrakis (2-pyridylmethyl) ethylenediamine (TPEN) can rapidly and reversibly chelate $\mathrm{Ca}^{2+}$ within E.R. stores without influencing $\left[\mathrm{Ca}^{2+}\right]_{c y t}$ for its low affinity with $\mathrm{Ca}^{2+}$ (Caroppo et al., 2003), which we applied to investigate further the role of $\mathrm{ER} \mathrm{Ca}^{2+}$ store in 

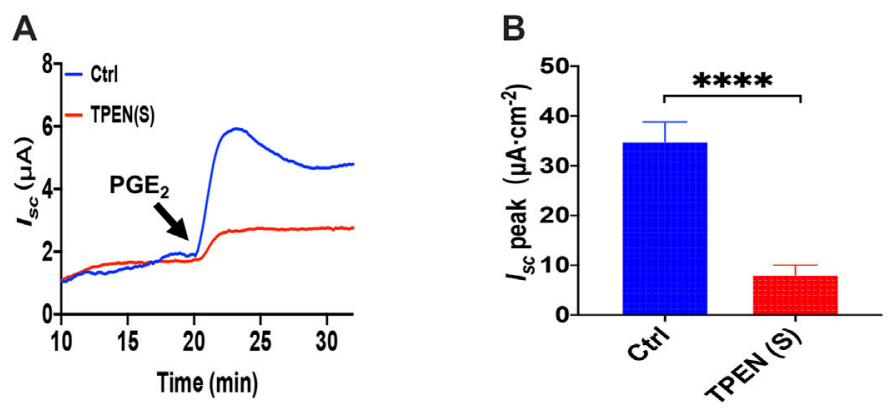

C

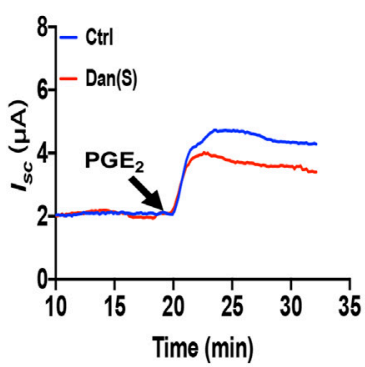

D

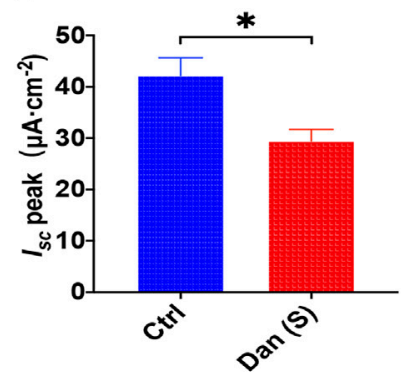

$\mathbf{E}$

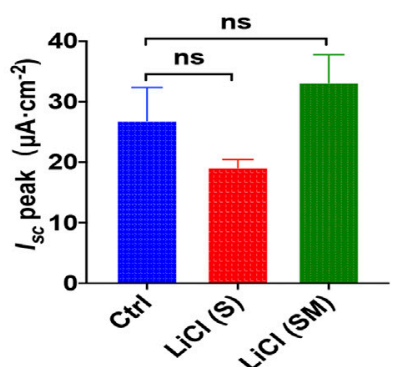

FIGURE 3 | The ER Ca ${ }^{2+}$ store and ryanodine receptors in $\mathrm{PGE}_{2}$-induced duodenal ion transports. (A,B) $\mathrm{PGE}_{2}(10 \mu \mathrm{M})$-evoked $I_{s c}$ after serosal $(\mathrm{s})$ application of

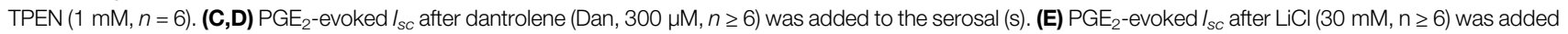
to the serosal side or both sides $(m+s)$. Ctrl represents the control without drug treatment. Results are presented as mean \pm SE. NS, no significant differences, ${ }^{*} p<0.05$, ${ }^{\star \star \star \star} p<0.0001$ vs. corresponding control by Student's unpaired, two-tailed t-test or one-way ANOVA followed by Dunnett's post-test.

PGE $E_{2}$-induced duodenal $I_{s c}$. As shown in Figures 3A,B, serosal addition of TPEN ( $1 \mathrm{mM}$ ) significantly suppressed $\mathrm{PGE}_{2}$-evoked $I_{s c}$. Considering ryanodine receptors (RyR) can mediate $\mathrm{Ca}^{2+}$ release from E.R., serosal addition of dantrolene $(300 \mu \mathrm{M})$, a selective RyR antagonist, markedly inhibited $\mathrm{PGE}_{2}$-induced $I_{s c}$ (Figures 3C,D), suggesting E.R. $\mathrm{Ca}^{2+}$ store release dominantly by the serosal side. As the inositol 1,4,5-triphosphate $\left(\mathrm{IP}_{3}\right)$ also leads to E.R. intracellular $\mathrm{Ca}^{2+}$ release through E.R. membrane by $\mathrm{IP}_{3}$ receptors (Lindqvist et al., 1998), we used $\mathrm{LiCl}(30 \mathrm{mM})$ that inhibits $\mathrm{IP}_{3}$ production, but $\mathrm{LiCl}$ added either on the serosal side or both sides of the tissues did not significantly alter $\mathrm{PGE}_{2^{-}}$ induced $I_{s c}$ (Figure 3E). These findings suggest that $\mathrm{PGE}_{2}$ acts via $\mathrm{RyR} / \mathrm{Ca}^{2+}$ rather than $\mathrm{IP}_{3} / \mathrm{Ca}^{2+}$ in E.R. to induce duodenal epithelial anion transports.

\section{Prostaglandin $\mathrm{E}_{2}$ Induced Duodenal Ion Secretion by Serosal Transient Receptor Potential Vanilloid 4 Channels and $\mathrm{Na}^{+} / \mathrm{K}^{+}$ ATPase}

Since that 2-APB, SKF-96365 and GSK-7975A also act on the transient receptor potential V(TRPV) family and that TRPV4 channels are expressed in the G.I. tract (Blackshaw et al., 2010), we tested if TRPV4 channel may represent the molecular constituents of CRAC channels in the process of the $\mathrm{PGE}_{2}$ stimulated duodenal $I_{s c}$. We all know that GSK1016790A, a highly selective agonist of TRPV4, can activate TRPV4 in diverse cells (Baratchi et al., 2019). However, unlike the effect in cultured cells detected in the ussing chamber at the tissue level, GSK1016790A alone had no effect on the basal $I_{s c}$ (Supplementary Figure S1). Hence we first chose the application of HC067047, a potent and selective TRPV4 antagonist (Xia et al., 2013), to block TRPV4 Channels. As shown in Figures 4A,B, serosal addition of HC067047 $(30 \mu \mathrm{M})$ suppressed $\mathrm{PGE}_{2}$-stimulated duodenal $I_{s c}$. Secondly, we compared $\mathrm{PGE}_{2}$-stimulated duodenal $I_{s c}$ between wild-type and TRPV4 KO mice. Duodenal $I_{s c}$ induced by serosal addition of $\mathrm{PGE}_{2}$ was significantly attenuated in TRPV4 KO mice (Figures 4C,D), while HC067047 $(30 \mu \mathrm{M})$ did not affect $\mathrm{PGE}_{2}$ evoked $I_{s c}$ of TRPV4 KO mice to exclude non-specific effects other than TRPV4 inhibition (Supplementary Figure S2). Thirdly, to further verify TRPV4 involved in the molecular composition of SOCE, we used SOCE and CRAC blocker, $\mathrm{Gd}^{3+}$, to test whether it works on TRPV4 knockout mice. $\mathrm{GdCl}_{3}(30 \mu \mathrm{M})$ serosal addition did not affect the $\mathrm{PGE}_{2}$-stimulated duodenal $I_{s c}$ of TRPV4 knockout mice. Above all, our findings are suggesting that TRPV4 is the molecular constituent of CRAC channels.

Since $\mathrm{Cl}^{-}$movement across the epithelial cells is facilitated by $\mathrm{Na}^{+} / \mathrm{K}^{+}$ATPase (NKA), we tested if it is involved in the process of $\mathrm{PGE}_{2}$-stimulated duodenal $I_{s c}$. Because NKA is exclusively expressed at the serosal side in the intestinal epithelium (Hammerton et al., 1991; Thorsen et al., 2014), addition of $1 \mathrm{mM}$ ouabain, a selective NKA inhibitor, to the serosal side completely abolished $\mathrm{PGE}_{2}$-induced duodenum $I_{s c}$ (Figures $\mathbf{4 F}, \mathbf{G})$, indicating that $\mathrm{NKA}$ participates in $\mathrm{PGE}_{2}$-mediated duodenal secretion. 

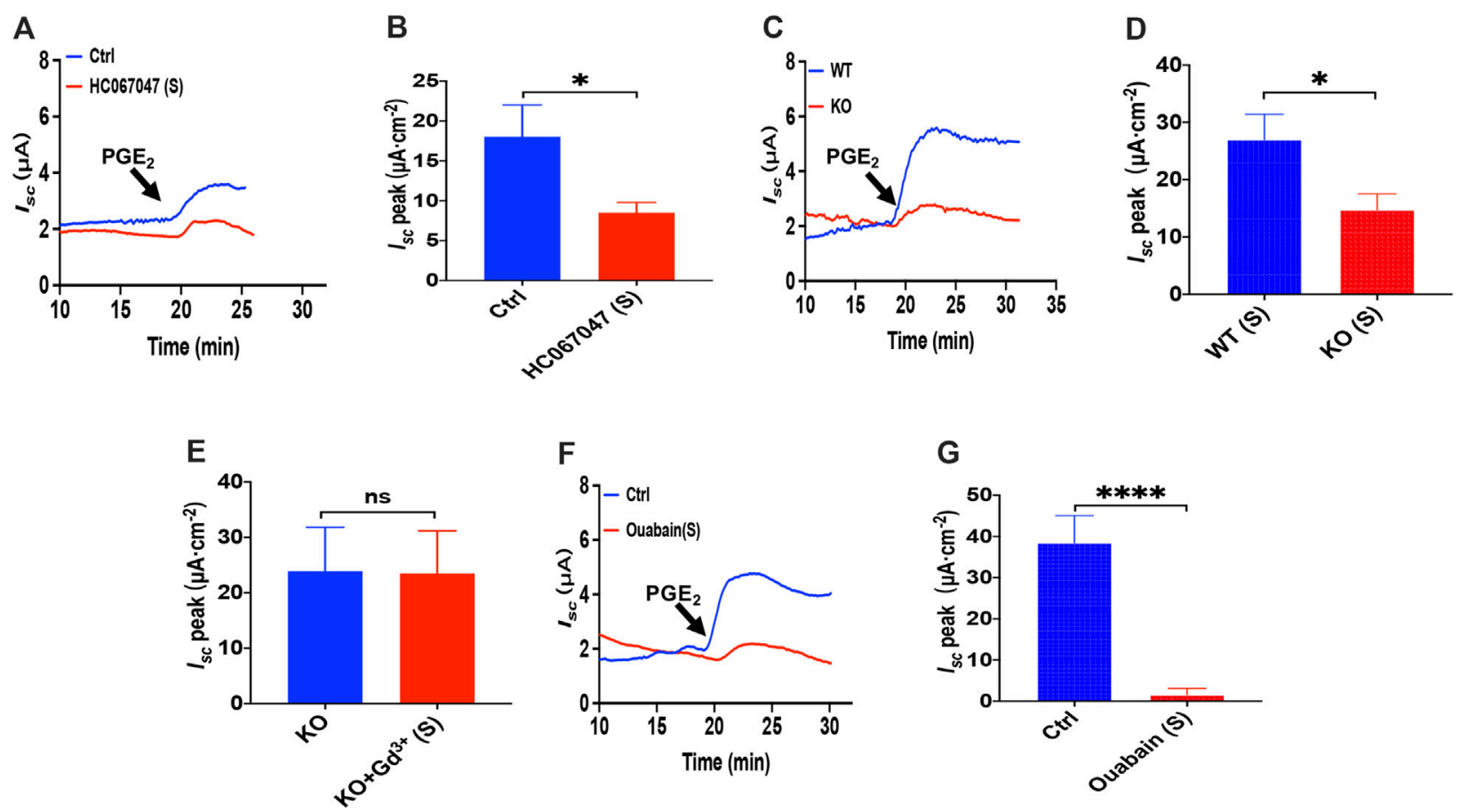

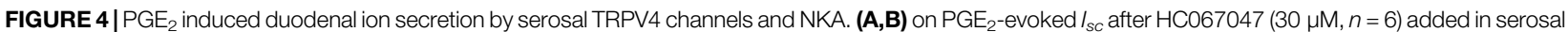
(s) side. (C,D) PGE $2(10 \mu \mathrm{M})$-evoked duodenal $I_{s c}$ in wild-type (W.T.) and TRPV4 knockout (K.O.) mice $(n=6)$. (E) PGE ${ }_{2}$-evoked $I_{s c}$ after GdCl 3 (Gd $\left.{ }^{3+}, 30 \mu M, n \geq 6\right)$ was

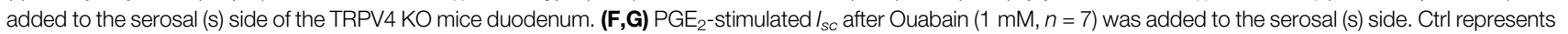
the control without drug treatment. Results are presented as mean $\pm \mathrm{SE}$. ${ }^{\star} p<0.05,{ }^{\star \star \star \star} p<0.0001$ significantly different from the corresponding control by Student's unpaired, two-tailed t-test.

\section{5-HT Induced $\mathrm{Ca}^{2+}$-Dependent Duodenal Epithelial Ion Transports}

When another important secretagogue, 5 -HT $(10 \mu \mathrm{M})$, was added to the serosal side, duodenal $I_{s c}$ increased, peaking within $2 \mathrm{~min}$, and then sustained for more than $10 \mathrm{~min}$ (Figures 5A,B). However, mucosal application of 5-HT or vehicle (DMSO) did not alter basal $I_{s c}$. Therefore, to test if $\mathrm{Ca}^{2+}$ is involved in the process of 5-HT-stimulated duodenal ion transports, we omitted extracellular $\mathrm{Ca}^{2+}$ of each side, and then we found that $5-\mathrm{HT}$ evoked $I_{s c}$ was markedly suppressed in either side of the duodenal tissues (Figures 5C,D). Therefore, 5-HT-stimulated duodenal ion transports are strongly $\mathrm{Ca}^{2+}$-dependent.

\section{5-HT Induced $\mathrm{Ca}^{2+}$-Dependent Intestinal Ion Secretion by Serosal Store-Operated $\mathrm{Ca}^{2+}$ Entry Mechanism}

Because it is still elusive for the mechanisms underlying 5-HT induced $\mathrm{Ca}^{2+}$-dependent duodenal ion secretion, we examined if the above mechanisms similar to $\mathrm{PGE}_{2}$ are involved. First, we utilized three antagonists of SOCE. 2-APB $(100 \mu \mathrm{M})$ application to the serosal side significantly suppressed 5-HT-evoked $I_{s c}$, but the mucosal side application did not affect $I_{s c}$ (Figures 6A,B). SKF-96365 $(30 \mu \mathrm{M})$ markedly decreased the $I_{s c}$ peak from serosal side application but not from the mucosal side of the duodenum
(Figures 6C,D). Hence, 5-HT also mediates SOCE mechanisms that act entirely on the duodenal serosal side, consistently with our findings with $\mathrm{PGE}_{2}$ described above.

We further identified if the CRAC channel is 5-HT-mediated SOCE in the duodenal epithelium by utilizing GSK-7975A and $\mathrm{Gd}^{3+}$. When GSK-7975A $(100 \mu \mathrm{M})$ was added to the serosal side, 5-HT-stimulated duodenal $I_{s c}$ is markedly inhibited in duodenal tissue (Figures 6E,F). Furthermore, $\mathrm{GdCl}_{3}(30 \mu \mathrm{M})$ application on the serosal side also significantly reduced 5-HT-stimulated duodenal $I_{s c}$ (Figures 6G,H). Therefore, 5-HT induced $\mathrm{Ca}^{2+}$ dependent intestinal ion secretion by serosal SOCE mechanism and probably CRAC channels.

\section{5-HT Induced Duodenal Ion Secretion via Serosal Transient Receptor Potential Vanilloid 4 Channels}

Like $\mathrm{PGE}_{2}$ experiments, we first chose HC067047, a potent and selective TRPV4 antagonist, to block TRPV4 channels. As shown in Figures 7A,B, serosal addition of HC067047 $(30 \mu \mathrm{M})$ suppressed the 5-HT-stimulated duodenal $I_{s c}$. Secondly, the duodenal $I_{s c}$ response to serosal application of 5-HT was significantly attenuated in TRPV4 knockout mice (Figures 7C,D), while HC067047 $(30 \mu \mathrm{M})$ did not affect $\mathrm{PGE}_{2}$ evoked $I_{s c}$ of TRPV4 KO mice to exclude non-specific effects other than TRPV4 inhibition (Supplementary Figure S3). Thirdly, $\mathrm{GdCl}_{3}$ 

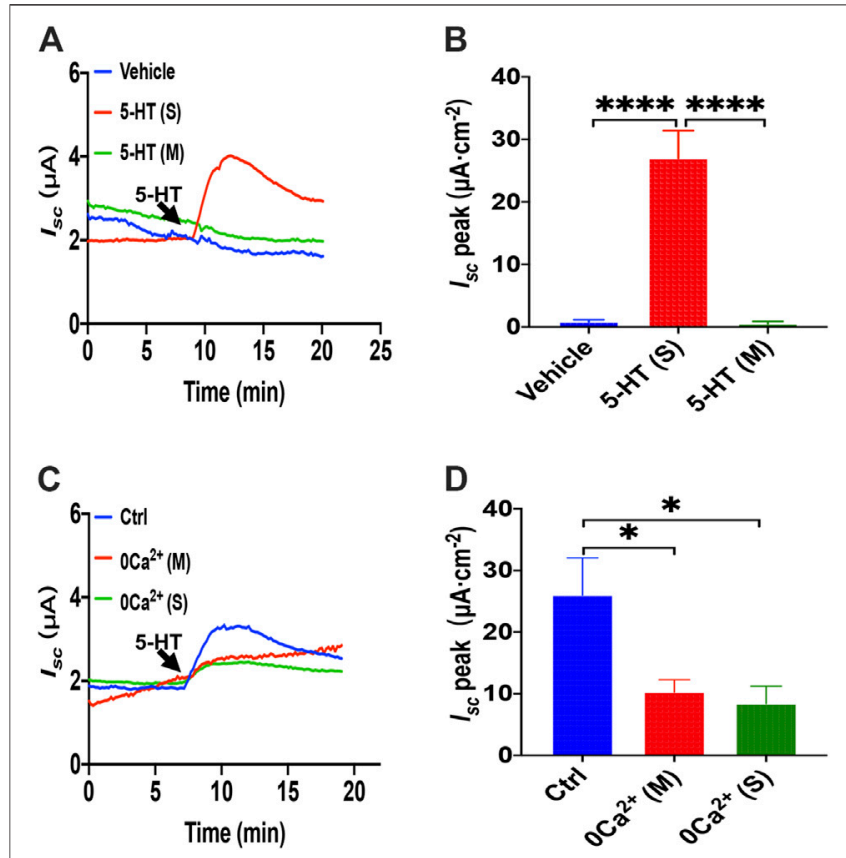

FIGURE 5 | 5-HT induced $\mathrm{Ca}^{2+}$-dependent duodenal epithelial ion transports. (A) Time courses of $5-\mathrm{HT}(10 \mu \mathrm{M})$-evoked $I_{s c}$ or vehicle (DMSO) when added to serosal (s) or mucosal side. (B) When added to the serosal or mucosal side, vehicle or $5-\mathrm{HT}$-evoked $I_{s c}$ peak $(n=6)$. (C) Time courses of 5-HT-evoked $I_{s c}$ after extracellular $\mathrm{Ca}^{2+}$ omission $\left(0 \mathrm{Ca}^{2+}\right)$ from each side in duodenal mucosal tissues. (D) 5-HT-evoked $I_{s c}$ peak after $\mathrm{Ca}^{2+}$ omission from each side (s or $\mathrm{m}, n=6$ ). Ctrl represents as the control in which normal extracellular $\mathrm{Ca}^{2+}$ was on both sides. Results are presented mean $\pm \mathrm{SE}$. ${ }^{*} p<$ $0.05,{ }^{\star \star \star \star} p<0.0001$ significantly different from the corresponding control by one-way ANOVA followed by Dunnett's post-test.

$(30 \mu \mathrm{M})$ serosal addition did not affect the 5-HT-stimulated duodenal $I_{s c}$ of TRPV4 knockout mice (Figure 7E). Therefore, the present studies suggest that TRPV4 is the molecular constituent of CRAC channels in the duodenum again.

\section{The ER $\mathrm{Ca}^{2+}$ Store and $\mathrm{IP}_{3} / \mathrm{Ca}^{2+}$ Signaling in 5-HT-Induced Intestinal Ion Transports}

To investigate how the ER $\mathrm{Ca}^{2+}$ store act in 5 -HT-evoked $I_{S \mathcal{O}}$ we added TPEN ( $1 \mathrm{mM})$ to serosal side of the duodenum and found that TPEN significantly inhibited 5-HT-stimulated $I_{s c}$ (Figures 8A,B), indicating a vital role of the $\mathrm{ER} \mathrm{Ca}^{2+}$ store in this course. Then we used $\mathrm{LiCl}$ $(30 \mathrm{mM})$ to inhibit $\mathrm{IP}_{3}$ production but dantrolene $(300 \mu \mathrm{M})$ to inhibit RyR. Interestingly, we found $\mathrm{LiCl}$ but not dantrolene significantly inhibited 5-HT-induced duodenal $I_{s c}$ (Figures 8C-E). Therefore, unlike $\mathrm{PGE}_{2}$, 5-HT induced duodenal epithelial anion transports via $\mathrm{IP}_{3} / \mathrm{Ca}^{2+}$ rather than $\mathrm{RyR} / \mathrm{Ca}^{2+}$ in the E.R.

\section{Luminal Carbachol Induced $\mathrm{Ca}^{2+}$-Dependent Duodenal $I_{s c}$ Through Serosal $\mathrm{Ca}^{2+}$ Entry}

We previously demonstrated a critical role of serosal SOCE mechanism mediated by $\mathrm{CCh}$, one of the most common and important secretagogues in $\mathrm{Ca}^{2+}$-dependent duodenal ion secretion. (Yang et al., 2018); however, it is not known if luminal addition of $\mathrm{CCh}$ can induce duodenal ion transports. Unlike $\mathrm{PGE}_{2}$ and 5-HT that act on seroal side of the duodenum exclusively (Figures 1A, 5A), we found that luminal addition of CCh $(100 \mu \mathrm{M})$ induced a significant duodenal $I_{s c}$ (Figure 9A), although it was only about one-third of that induced by serosal addition (Figure 9B). To verify whether the action of luminal $\mathrm{CCh}$ is through the muscarinic receptors, atropine, a muscarinic receptor antagonist, was applied. As shown in Figures 9C,D, atropine $(10 \mu \mathrm{M})$ added in mucosal side markedly attenuated luminal CCh-induced $I_{s c}$ indicating that luminal CCh evokes duodenal $I_{s c}$ via specific activation of muscarinic receptors expressed on the mucosal side of epithelial cells as well.

To test the extracellular $\mathrm{Ca}^{2+}$ effect in $\mathrm{CCh}$-induced duodenal $I_{s c}$, we omitted extracellular $\mathrm{Ca}^{2+}$ in each side of the tissues. Figures 9E,F show that luminal CCh-evoked $I_{s c}$ was markedly suppressed when $\mathrm{Ca}^{2+}$ has omitted on the serosal side but not the mucosal side. Furthermore, we verified further that nifedipine $(10 \mu \mathrm{M})$, an L-type calcium channel blocker, did not inhibit luminal CCh-induced $I_{s c}$ either (Figure 9G). Together, these findings indicate that even luminal $\mathrm{CCh}$ induced $\mathrm{Ca}^{2+}$ dependent duodenal $I_{s c}$ through serosal $\mathrm{Ca}^{2+}$ entry, further supporting our previous notion that $\mathrm{CCh}$ induced $\mathrm{Ca}^{2}$ dependent duodenal $I_{s c}$ by serosal SOCE mechanism exclusively (Yang et al., 2018).

\section{Luminal Carbachol Induced}

\section{$\mathrm{Ca}^{2+}$-Dependent Duodenal $I_{s c}$ via Transient Receptor Potential Vanilloid 4-Constituted Store-Operated $\mathrm{Ca}^{2+}$ Entry}

As $\mathrm{Gd}^{3+}$ is a potential blocker of SOCE and CRAC/Orai channel, we added $\mathrm{GdCl}_{3}(30 \mu \mathrm{M})$ in the serosal side to test if it affects the luminal $\mathrm{CCh}$ induced $\mathrm{Ca}^{2+}$-dependent duodenal $I_{s c}$. As shown in Figures 10A,B, $\mathrm{Gd}^{3+}$ significantly reduced luminal CChstimulated duodenal $I_{s c}$, which suggested luminal CCh evokes anion secretion through SOCE mechanisms.

To verify that TRPV4 is the molecular constituent of CRAC channels in the duodenum, we compared $\mathrm{PGE}_{2}$-stimulated duodenal $I_{s c}$ between wild-type and TRPV4 KO mice. As shown in Figures 10C,D, duodenal $I_{s c}$ induced by serosal addition of luminal $\mathrm{CCh}$ was significantly attenuated in TRPV4 $\mathrm{KO}$ mice. Meanwhile, $\mathrm{GdCl}_{3}(30 \mu \mathrm{M})$ serosal addition did not affect luminal CCh-stimulated duodenal $I_{s c}$ of TRPV4 knockout mice (Figure 10E), further indicating that luminal CCh induced $\mathrm{Ca}^{2+}$-dependent duodenal anion secretion via TRPV4constituted SOCE.

\section{Activator of Store-Operated $\mathrm{Ca}^{2+}$ Entry in the Duodenal Epithelium and TRPV4-Constituted Store-Operated $\mathrm{Ca}^{2+}$ Entry Mechanism in IECs}

As we have already known that cyclopiazonic acid (CPA), an ER$\mathrm{Ca}^{2+}$-ATPase inhibitor (Dolmetsch and Lewis, 1994), can activate SOCE (Bird et al., 2008), TPEN also evoked SOCE by chelating 

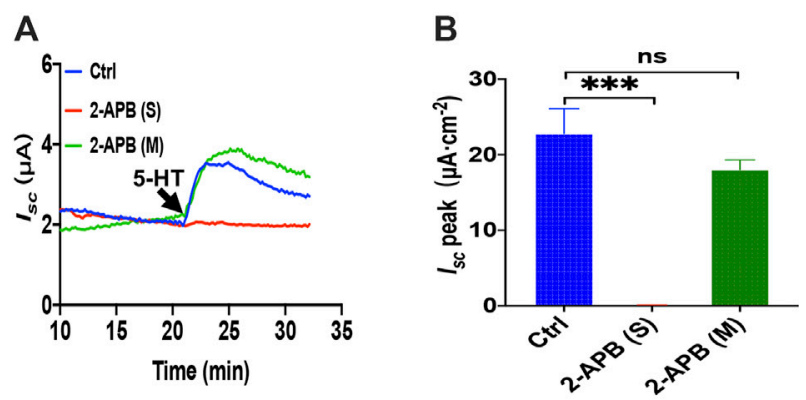

$E$

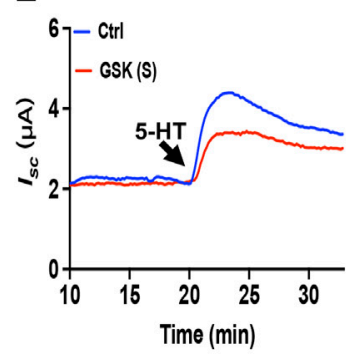

C

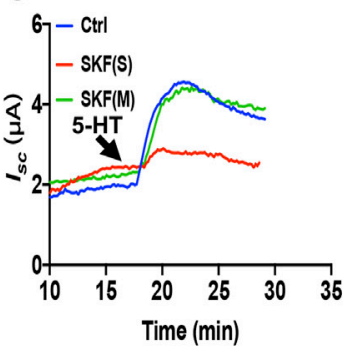

G

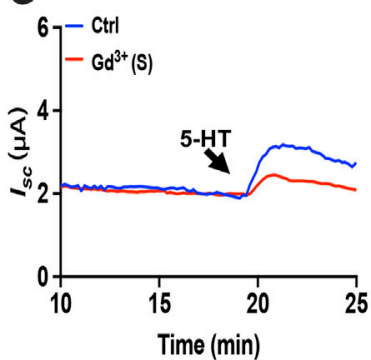

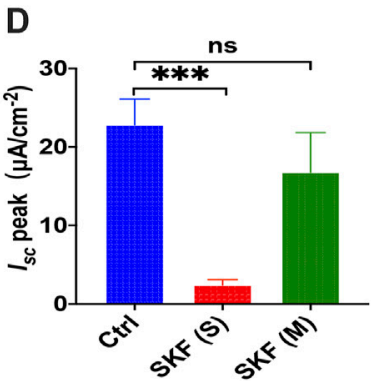

$\mathrm{H}$

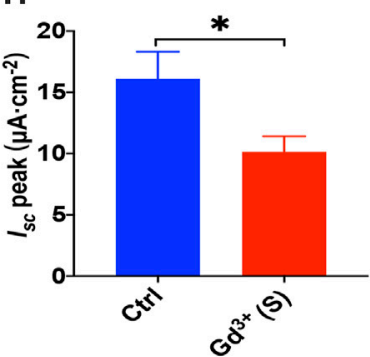

FIGURE 6 | 5-HT induced $\mathrm{Ca}^{2+}$-dependent intestinal ion secretion by serosal SOCE mechanism in mice duodenum. (A) Time course of 5-HT-evoked sc $_{\text {after } 2-}$ aminoethoxydiphenyl borate (2-APB, $100 \mu \mathrm{M}, n=6$ ) added to the serosal or mucosal side. (B) 5-HT-stimulated murine duodenal $I_{s c}$ peak after 2-APB was added to the serosal or mucosal side. (C) Time course of 5-HT-evoked $I_{s c}$ after SKF-96365 (SKF, $30 \mu \mathrm{M}, n=6$ ) added to the serosal or mucosal side. (D) 5-HT-evoked duodenal $I_{s c}$ peak after SKF-96365 was added to the serosal or mucosal side. (E) Time course of 5-HT-evoked $I_{s c}$ after GSK-7975A (GSK, $100 \mu M, n=6$ ) added to the serosal side. (F) 5-HT-evoked $I_{s c}$ peak after GSK-7975A was added to the serosal side. (G-H) $5-H T$-evoked $I_{s c}$ after $\mathrm{GdCl}_{3}\left(\mathrm{Gd}{ }^{3+}, 30 \mu \mathrm{M}, n=6\right)$ added to the side. Ctrl represents the control without drug treatment. Results are presented as mean \pm SE. NS, no significant differences, ${ }^{\star} p<0.05$, ${ }^{\star \star \star} p<0.001$ vs. corresponding control by Student's unpaired, two-tailed t-test or one-way ANOVA followed Dunnett's post-test.

$\mathrm{Ca}^{2+}$ within E.R. (Gwozdz et al., 2012). The addition of CPA $(10 \mu \mathrm{M})$ in the serosal induced a transient high $I_{s c}$ peak with a sustained phase following (Figure 11A), and the addition of $\mathrm{GdCl}_{3}$ $(30 \mu \mathrm{M})$ in the serosal side significantly reduced CPA-stimulated duodenal $I_{s c}$ (Figures 11A,B). The addition of TPEN $(1 \mathrm{mM})$ in the serosal induced a transient high $I_{s c}$ peak with a sustained phase following (Figures 11C,E), while the addition of $\mathrm{GdCl}_{3}(30 \mu \mathrm{M})$ and $\mathrm{HC} 067047(30 \mu \mathrm{M})$ in the serosal side significantly reduced TPEN-stimulated duodenal $I_{s c}$ (Figures 11C-F).

Our former studies, including T29 (Yang et al., 2018) and SCBN (Zhang et al., 2019; Zhang et al., 2021), confirmed that SOCE/ORAC mechanism is in IECs through SOCE blockers or knockdown cells. IEC-6 cells are usually applied as an IEC model to study intestine epithelial anion secretion (Wenzl et al., 1989), which has also been certificated the participation of SOCE mechanism (Chung et al., 2015). Meanwhile, TRPV4 expressed in IEC-6 cells basolateral and GSK1016790A induced $\left[\mathrm{Ca}^{2+}\right]_{\mathrm{cyt}}$ rising were suppressed by pretreatment with RN1734 or extracellular $\mathrm{Ca}^{2+}$ omission in IEC-6 cells (Yamawaki et al., 2014). So we measured $\left[\mathrm{Ca}^{2+}\right]_{\text {cyt }}$ in IEC-6 cells to test the TRPV4 constituent SOCE mechanism. Superfused with $\mathrm{Ca}^{2+}$ free solution $(0 \mathrm{Ca}), \mathrm{CPA}(10 \mu \mathrm{M})$, and TPEN $(50 \mu \mathrm{M})$, first induced a rapid increase in $\left[\mathrm{Ca}^{2+}\right]_{\mathrm{cyt}}$ in IEC- 6 cells as a result of ER $\mathrm{Ca}^{2+}$ release (Figures 12A,D). After completion of $\mathrm{Ca}^{2+}$ release from E.R., the restoration of extracellular $\mathrm{Ca}^{2+}(2 \mathrm{Ca})$ caused an enhanced increase in $\left[\mathrm{Ca}^{2+}\right]_{\text {cyt }}$ owing to the SOCE mechanism (Figures 12A,D). As shown in Figures 12B,C,E,F, HC067047 $(10 \mu \mathrm{M})$, a commonly used TRPV4 blocker in IEC-6, significantly inhibited CPA-and TPEN-induced SOCE, further advocating that TRPV4 participates in the composition of SOCE.

\section{DISCUSSION}

Albeit it is well recognized that the critical role of calcium signaling in epithelial ion transports of the salivary gland, pancreatic ducts, and colonic epithelia, the detailed regulatory in the small intestinal epithelial and the underlying molecular mechanisms are not fully understood. Our research demonstrates that: 1) serosal $\mathrm{PGE}_{2}$ stimulates anion secretion mainly through $\mathrm{RyR} / \mathrm{ER} \mathrm{Ca}^{2+}$ release-initiated serosal SOCE mechanism; however, serosal 5-HT and luminal CCh stimulate anion secretion mainly through $\mathrm{IP}_{3} \mathrm{R} / \mathrm{ER} \mathrm{Ca}^{2+}$ release-initiated serosal SOCE mechanisms. 2) CARC may act as the SOCE mechanism in the process of $\mathrm{Ca}^{2+}$-dependent anion secretion. 3) TRPV4 channels may represent the molecular constituents of serosal SOCE/CARC channels to mediate $\mathrm{Ca}^{2+}$-dependent anion secretion. Therefore, our results indicate that $\mathrm{Ca}^{2+}$ signaling is essential for three most common and important secretagogues-induced small intestinal anion secretion, in which serosal TRPV4-constituted SOCE mechanism may play a critical role. Thus, our findings supple a novel insight into the molecular mechanisms of secretagogues-mediated epithelial anion secretion via $\mathrm{Ca}^{2+}$ signaling. 

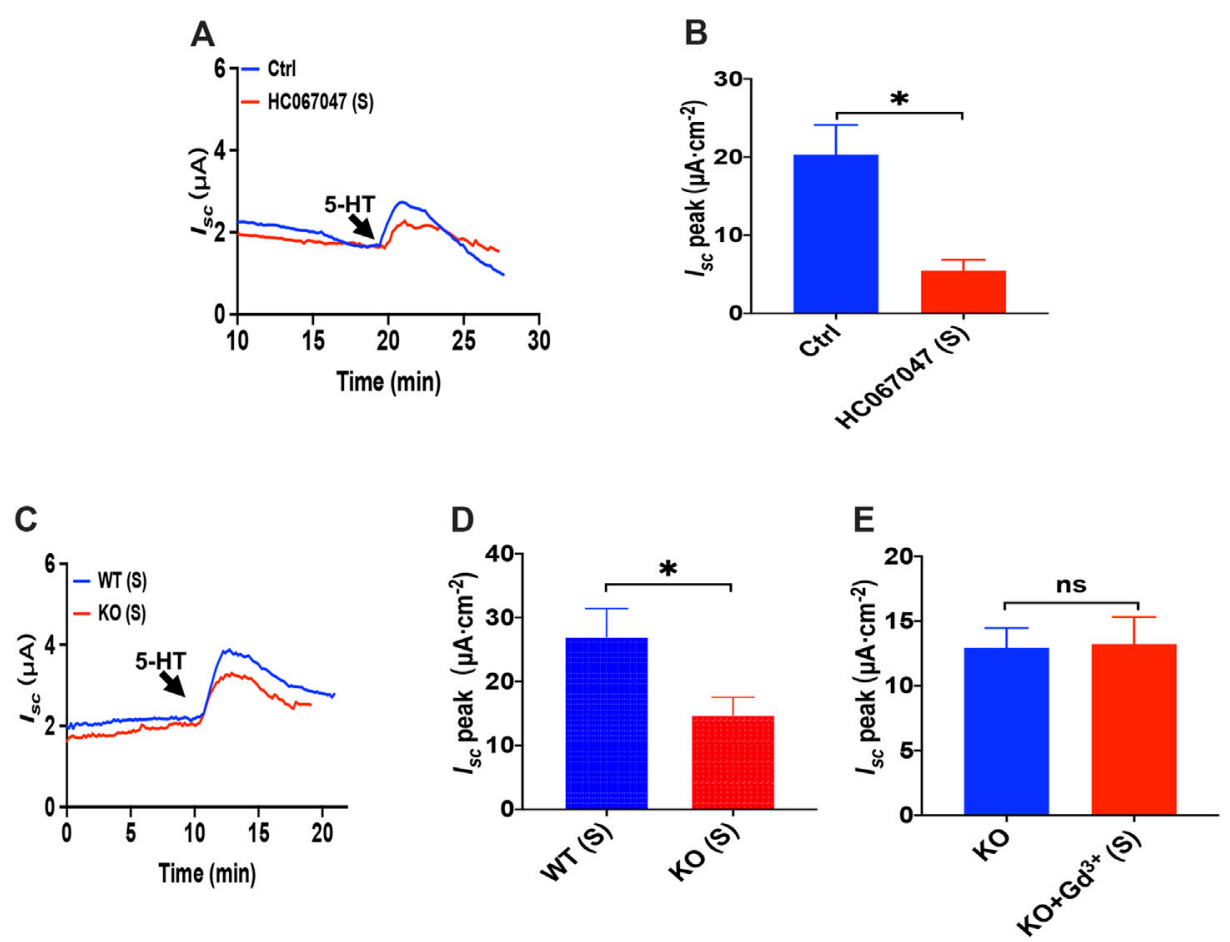

FIGURE 7 | 5-HT induced duodenal ion secretion via serosal TRPV4 channels. (A,B) 5 -HT-evoked $/ s c$ after HC067047 (30 $\mu \mathrm{M}, n=6)$ was added to the serosal (s) side. (C,D) $5-\mathrm{HT}(10 \mu \mathrm{M})$-evoked $I_{s c}$ in wild-type (W.T.) or TRPV4 knockout (K.O.) mice $(n=6)$. (E) 5 -HT-evoked $I_{s c}$ after GdCl $\left(\mathrm{Gd}^{3+}, 30 \mu \mathrm{M}, n=6\right)$ was added to the serosal (s) side of the TRPV4 KO mice duodenum. Ctrl represents the control without drug treatment. Results are presented as mean \pm SE. NS, no significant differences, ${ }^{*} p<0.05$ vs. corresponding control by Student's unpaired, two-tailed t-test.
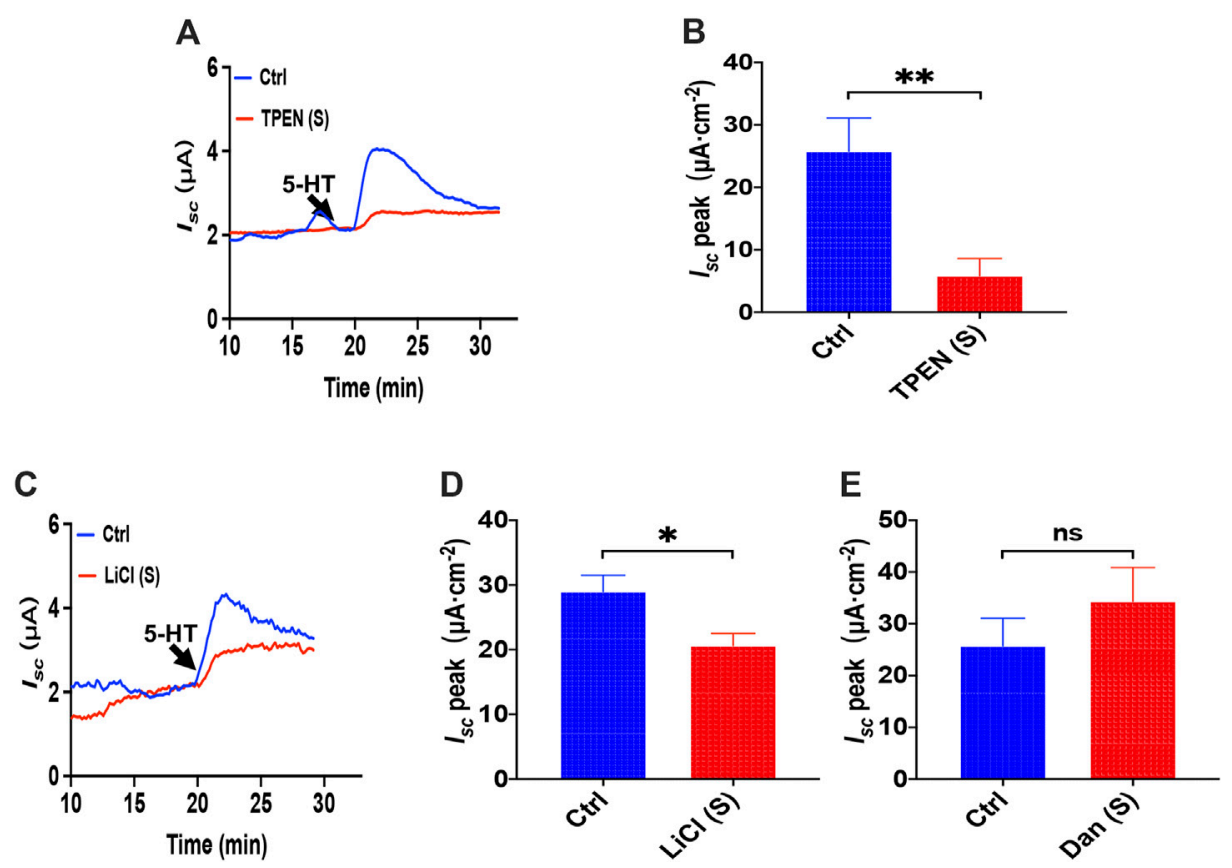

FIGURE 8| The ER Ca ${ }^{2+}$ store and $\mathrm{IP}_{3} / \mathrm{Ca}^{2+}$ signaling in 5-HT-induced intestinal ion transports. (A,B) 5 - $\mathrm{HT}$-evoked duodenal $/ s c$ after TPEN $(1 \mathrm{mM}, n=6)$ added to serosal (s) side. (C,D) $5-H T$-evoked $I_{s c}$ after $\mathrm{LiCl}(30 \mathrm{mM}, n=6)$ was added to the serosal (s) side. (E) 5 -HT-evoked $l_{s c}$ after dantrolene (Dan, $\left.100 \mu \mathrm{M}, n=6\right)$ was added to the serosal side. Ctrl represents the control without drug treatment. Results are presented as mean \pm SE. NS, no significant differences, ${ }^{*} p<0.05,{ }^{\star \star} p<0.01$ vs. corresponding control by Student's unpaired, two-tailed t-test. 

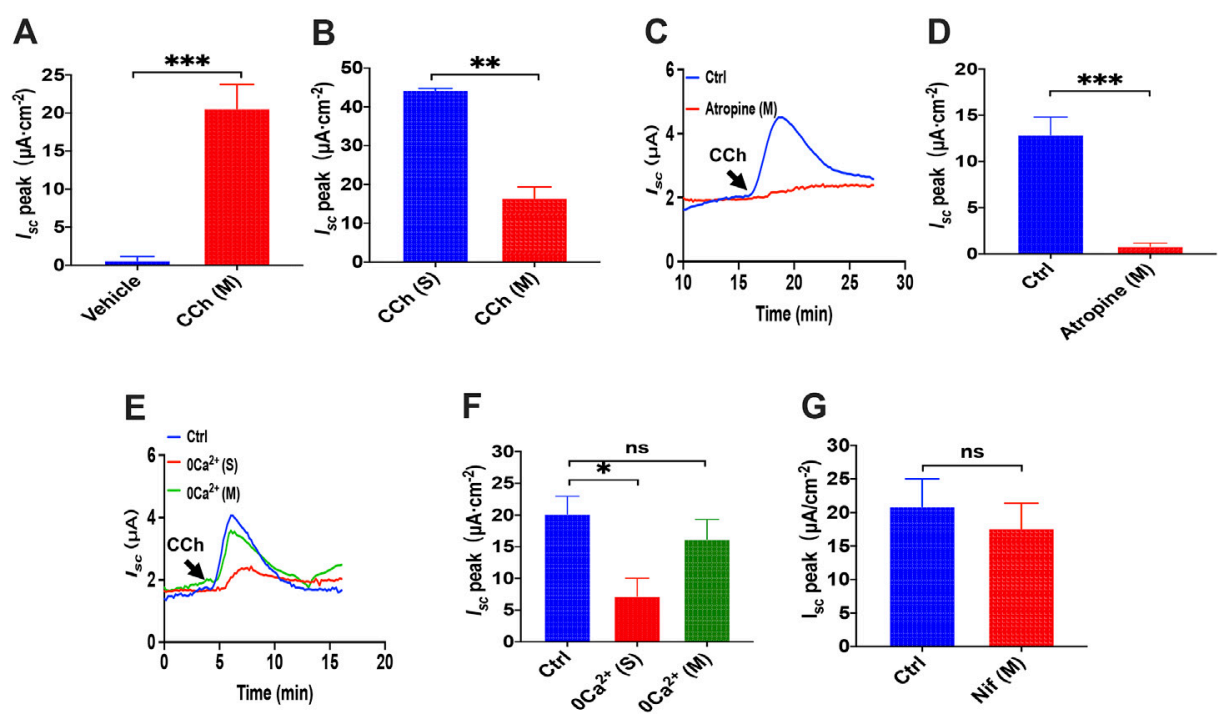

FIGURE 9 | luminal CCh induced $\mathrm{Ca}^{2+}$-dependent duodenal $I_{s C}$ through serosal $\mathrm{Ca}^{2+}$ entry. (A) Summary data of vehicle $\left(\mathrm{H}_{2} \mathrm{O}\right)$ or $\mathrm{CCh}(100 \mathrm{\mu M})$-stimulated $I_{\mathrm{sC}}$ peak after mucosal application $(n=6)$. (B) Comparison between CCh-evoked $I_{s C}$ peak after mucosal and serosal application. (C,D) luminal CCh-induced duodenal $I_{s C}$ after atropine $(10 \mu \mathrm{M}, n=6)$ added to the mucosal side. Ctrl represents the control without atropine treatment. (E,F) luminal CCh-evoked $I_{s c}$ after extracellular Ca ${ }^{2+}$ omitted from the serosal or mucosal side $(n=6)$. Ctrl represents as the control in which normal extracellular Ca ${ }^{2+}$ was on both sides. (G) luminal CCh-evoked duodenal $I_{s c}$ after mucosal addition of Nifedipine (Nif, $10 \mu \mathrm{M}, n=6$ ). Ctrl represents the control without Nif treatment. Results are presented as mean \pm SE. ${ }^{\star} p<0.05,{ }^{* \star} p<$ $0.01,{ }^{\star \star \star} p<0.001$ vs. corresponding control by Student's unpaired, two-tailed t-test.

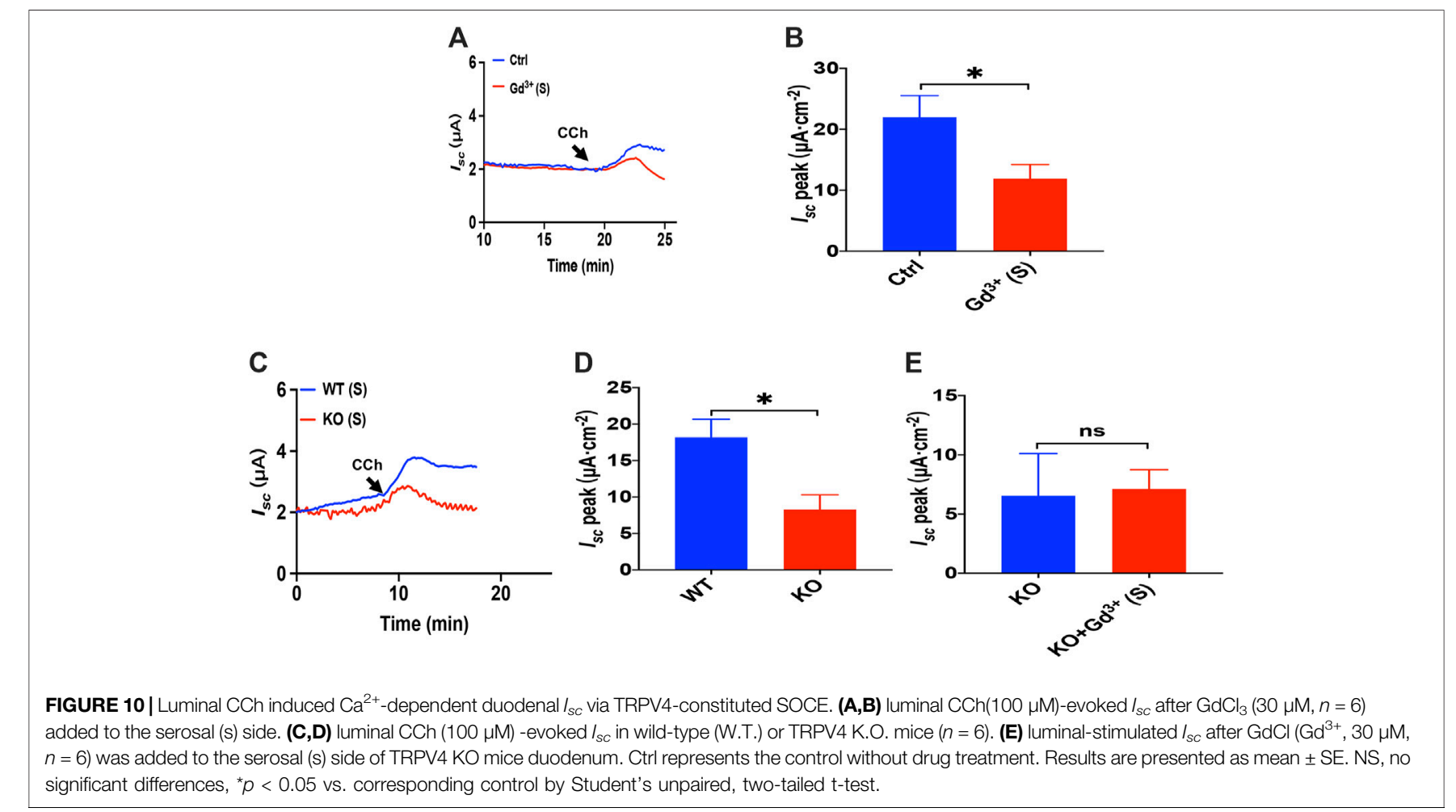



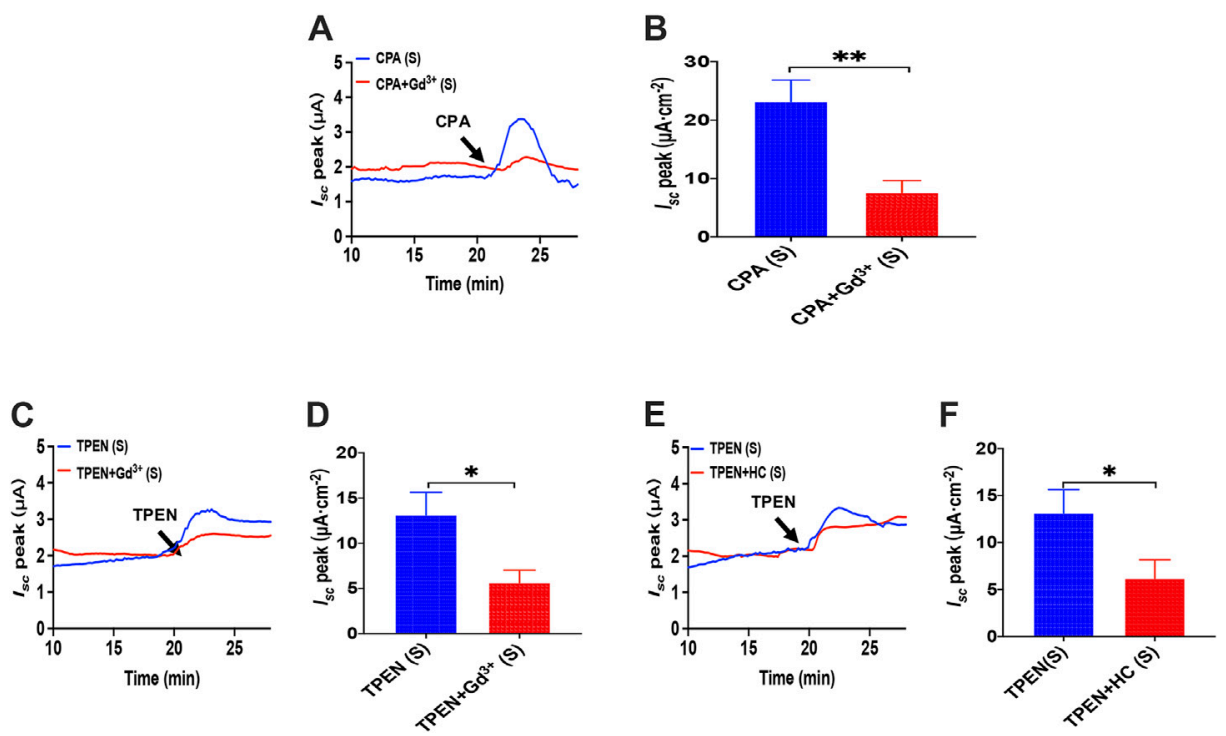

FIGURE 11 | Activator of SOCE in the duodenal epithelium. (A,B) serosal CPA(10 $\mu \mathrm{M})$-stimulated duodenal $I_{S C}$ after addition of $\mathrm{GdCl}{ }_{3}(30 \mu \mathrm{M})$ in the serosal side $(n=6)$. (C,D) TPEN-stimulated duodenal $I_{S C}$ after addition of $\mathrm{GdCl} 3(30 \mu \mathrm{M})$ in the serosal side $(n=6)$. (E,F) TPEN-stimulated duodenal $I_{S C}$ after adding HC067047 $(30 \mu \mathrm{M})$ to the serosal side $(n=6)$. Ctrl represents the control without drug treatment. Results are presented as mean \pm SE. NS, no significant differences, ${ }^{\star} p<0.05,{ }^{\star \star} p<$ 0.01 vs. corresponding control by Student's unpaired, two-tailed t-test.
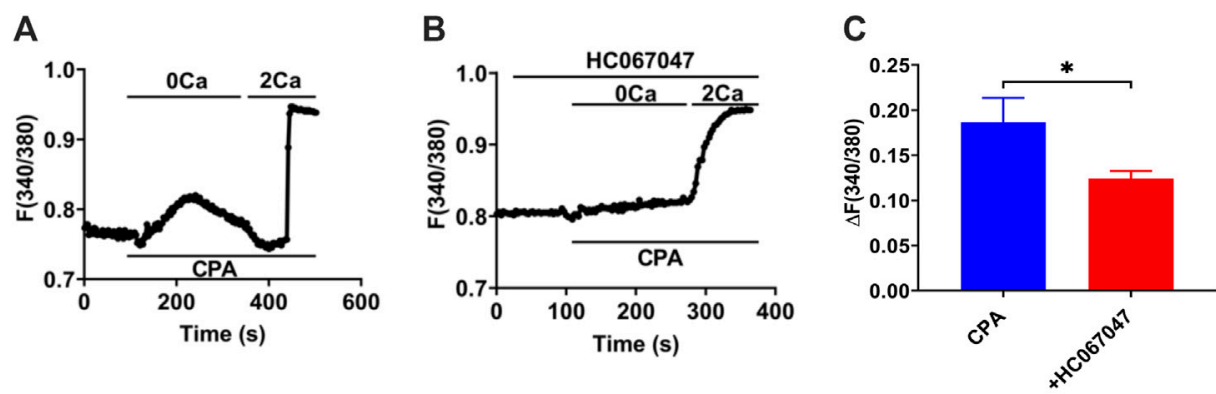

D

E

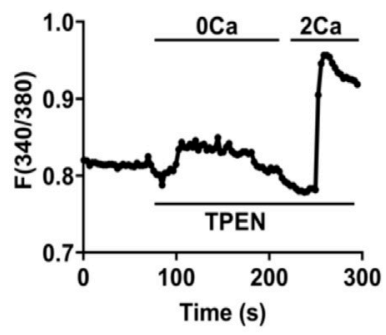

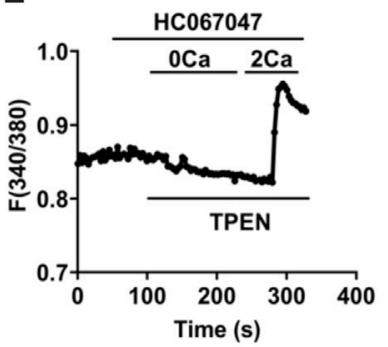

$\mathbf{F}$

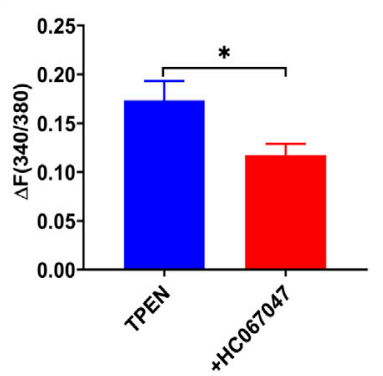

FIGURE 12 | TRPV4-constituted SOCE mechanism in IECs. (A)Time courses of CPA (10 $\mu \mathrm{M})$-induced $\mathrm{Ca}^{2+}$ signaling in the extracellular $\mathrm{Ca}{ }^{2+}$ omission $(0 \mathrm{Ca}$, left) or not (2 Ca, right) in ICE-6 cells. (B) Time courses of CPA-evoked $\mathrm{Ca}^{2+}$ signaling with $\mathrm{HC} 067047$ (30 $\left.\mu \mathrm{M}\right)$ pretreated in extracellular $\mathrm{Ca}^{2+}$ omission or not. (C) $\mathrm{CPA}$ induced $\left[\mathrm{Ca}^{2+}\right]_{\mathrm{cyt}}$ mobilization with $\mathrm{HC} 067047(30 \mu \mathrm{M})$ pretreated in HEC-6 cells superfused with $\mathrm{Ca}^{2+}$ - containing solution (2 Ca). Results are presented as mean SE ( $n=25-35$ cells). (D) TPEN (50 $\mu \mathrm{M})$-evoked $\mathrm{Ca}^{2+}$ signaling in the extracellular $\mathrm{Ca}^{2+}$ omission (0 Ca, left) or not (2 Ca, right) in ICE-6 cells. (E) TPEN-evoked Ca ${ }^{2+}$ signaling with $\mathrm{HC} 067047(30 \mu \mathrm{M})$ pretreated in extracellular $\mathrm{Ca}^{2+}$ omission or not. (F) TPEN-induced $\left[\mathrm{Ca}^{2+}\right]_{\text {cyt }}$ mobilization with $\mathrm{HC} 067047$ (30 $\left.\mu \mathrm{M}\right)$ pretreated in $\mathrm{HEC}-6$ cells superfused with $\mathrm{Ca}^{2+}$ - containing solution (2 Ca). Results are presented as mean SE $(n=25-35 \text { cells })^{\star} p<0.05$ vs. corresponding control by Student's unpaired, two-tailed t-test. 
Being a prevalent second messenger, $\left[\mathrm{Ca}^{2+}\right]_{\mathrm{cyt}}$ serve to regulate numerous cellular functions in various mammalian cells (Berridge et al., 2003), and it has been an essential regulator for intestinal epithelial ion secretion (Chew et al., 1998; Flemström and Isenberg, 2001; Jung and Lee, 2014). However, compared with excitable cells in which $\mathrm{Ca}^{2+}$ entry is mainly through VGCC, less is known about $\mathrm{Ca}^{2+}$ entry in non-excitable intestinal epithelial cells since functional VGCC may not be expressed (Parekh and Penner, 1997). In our research, we firstly confirmed the essential role of pure $\mathrm{Ca}^{2+}$ signaling in three secretagogues-induced small intestine anion secretion by using native mice duodenal epithelium, and then we revealed that they induced $\mathrm{Ca}^{2+}$ entry from the serosal side rather than from the mucosal side, which is consistent with our previous study (Yang et al., 2018). This phenomenon may be due to the following facts: 1) most secretagogues are derived from enterochromaffin (E.C.) cells or enteric neurons and transferred from the bloodstream, 2) their corresponding receptors are predominately located on the serosal side of intestinal epithelium, and 3) external $\mathrm{Ca}^{2+}$ concentrations in interstitial fluid of epithelia are maintained relatively consistent under physiological conditions.

It is well known that muscarinic receptors predominately express on the serosal side of the intestinal epithelium. However, we revealed for the first time that luminal CCh also evoked a significant duodenal $I_{s \mathcal{O}}$ which was inhibited by mucosal application of muscarinic receptor antagonist and omission of serosal calcium, suggesting that luminal CCh also activates mucosal muscarinic receptor to media $\mathrm{Ca}^{2+}$ entry from serosal side instead of mucosal side of duodenal epithelium. These new findings are not only mostly consistent with those obtained from our previous study but extend them (Yang et al., 2018). Although the muscarinic receptors in pancreatic acinar cells are localized to the apical side (Ashby et al., 2003), they are still elusive for their localization on the apical side of duodenal epithelial cells and their physiological significance. It was previously reported that bile acids might interact with apical muscarinic receptors on gastric chief cells and intestinal cells (Raufman et al., 2003); however, the detailed localization and significance of apical muscarinic receptors in the G.I. tract need further investigation.

Previous studies demonstrated that the serosal addition of CCh triggers $\mathrm{IP}_{3} / \mathrm{IP}_{3} \mathrm{R} / \mathrm{ER} \mathrm{Ca}^{2+}$ release that stimulates serosal SOCE mechanisms and ultimately induces $\mathrm{Ca}^{2+}$-dependent duodenal anion secretion (Yang et al., 2018; Zhang et al., 2019). Here, we further examined if $\mathrm{PGE}_{2}$ and 5-HT induced intestinal anion secretion through serosal SOCE mechanism. First, either omission of extracellular $\mathrm{Ca}^{2+}$ or $\mathrm{ER} \mathrm{Ca}^{2+}$ chelation markedly attenuated $\mathrm{PGE}_{2}-$ and 5-HT-induced duodenal $I_{s c}$. Second, relatively selective SOCE blockers with different chemical structures significantly inhibited $\mathrm{PGE}_{2^{-}}$and 5-HT-induced duodenal $I_{s c}$ from serosal side instead of mucosal side of the duodenum. Third, GSK-7975A and $\mathrm{Gd}^{3+}$, selective $I_{\text {CRAC }}$ blockers (Bird et al., 2008; Derler et al., 2013; Sataloff et al., 2017), also inhibited $\mathrm{PGE}_{2}$ - and 5-HT-evoked $I_{s c}$ from serosal side. Therefore, together with our previous studies, these findings support a universal role of serosal SOCE mechanism in $\mathrm{Ca}^{2+}$-dependent duodenal anion secretion induced by three most common secretagogues.

Furthermore, we reveal a difference between them: 1) dantrolene, a selective RyR antagonist, inhibited $\mathrm{PGE}_{2}$-induced but not 5-HT-induced duodenal $\left.I_{s c} ; 2\right) \mathrm{LiCl}$, an inhibitor of $\mathrm{IP}_{3}$ production attenuated 5-HT-induced but not $\mathrm{PGE}_{2}$-induced $I_{s c}$. These findings suggest that $\mathrm{ER} \mathrm{Ca}^{2+}$ release may be induced via different pathways: $\mathrm{PGE}_{2}$ and 5 -HT activate RyR and $\mathrm{IP}_{3} \mathrm{R}$, respectively. Although $\mathrm{ER} \mathrm{Ca}^{2+}$ release is mainly mediated by two well-known channels RyR and $\mathrm{IP}_{3} \mathrm{R}$, they have different $\mathrm{Ca}^{2+}$ affinities (Carreras-Sureda et al., 2018). 5-HT couples to $\mathrm{IP}_{3} / \mathrm{IP}_{3} \mathrm{R}$ signaling pathway in glioma cells, which subsequently cause intracellular $\mathrm{Ca}^{2+}$ release (Noda et al., 2003). In contrast, $\mathrm{PGE}_{2}$ induces $\mathrm{Ca}^{2+}$ release through $\mathrm{RyR}$ in bovine adrenal medullary cells (Shibuya et al., 2002). The concentration of dantrolene $(300 \mu \mathrm{M})$ in our research is relatively high. However, it is consistent with our previous study (Zhang et al., 2019) that serosal application of dantrolene $(100 \mu \mathrm{M})$ caused significant inhibition of caffeine-induced $I_{s c}$, and an increase in the concentration of dantrolene $(300 \mu \mathrm{M}$ and $1 \mathrm{mM})$ dosedependently enhanced the inhibition. However, whether the high concentration of dantrolene has a non-specific effect needs further investigation in RyR $\mathrm{KO}$ mice or cell lines. Moreover, 2-APB is a non-specific IP3R inhibitor, so we chose to examine the involvement of $\mathrm{IP}_{3} \mathrm{R}$ by inhibition of $\mathrm{IP}_{3}$ with $\mathrm{LiCl}$. Further experiments in K.O. mice or cell lines may be needed to verify IP3R involvement in Isc and SOCE further.

Molecular components of SOCE in intestinal epithelial cells have not been well identified. They are considered as TRPC1 in IEC (Rao et al., 2006) or STIM1/Orail in rat colonic epithelium (Onodera et al., 2013) and Caco2 cells (Yang et al., 2018). TRPV4 channels are nonselective cation channels with higher permeability for $\mathrm{Ca} 2+$ (Gees et al., 2010) and expressed on the G.I. tract (Balemans et al., 2017). It was previously reported that SOCE could be constituted by TRPV4 alone or together with TRPC1 to form a heteromeric channel (Ma et al., 2011). Therefore, using TRPV4 antagonist and TRPV4KO mice, we examined if it represents molecular components of SOCE in mouse native duodenum. Indeed, we demonstrate that TRPV4 channels may constitute SOCE to contribute to $\mathrm{PGE}_{2}$ and 5-HT-induced $\mathrm{Ca}^{2+}$-dependent duodenal anion secretion for the first time. In the meantime, we adopted a TRPV4 blocker to suppress SOCE activation in the IEC- 6 cell line, which elucidates that TRPV4 participates in SOCE. However, GSK1016790A alone had no effect on the basal Isc in W.T., and K.O. mice, which could be due to the fact that directly opening TRPV4 channel itself may not be sufficient to cause calcium influx in situ because TRPV4 is only one of many components for SOCE activation, including STIM1, Orai, TRPC channels.

Although the role of TRPV4 channels in G.I. disease has been broadly examined (Vergnolle, 2014), their physiological roles in the gut are still elusive, which need further investigation.

In conclusion, we underscore an essential role of $\mathrm{Ca}^{2+}$ signaling mediated anion secretion by TRPV4-constituted serosal SOCE mechanisms, which is universal for the three most common and important secretagogues. Although $\mathrm{PGE}_{2}$ and 5-HT stimulate this mechanism exclusively from serosal side of the duodenum, $\mathrm{CCh}$ stimulates it from both sides. We also reveal that 5-HT and CCh trigger $\mathrm{ER} \mathrm{Ca}^{2+}$ release to initiate SOCE likely via $\mathrm{IP}_{3} / \mathrm{IP}_{3} \mathrm{R}$, but $\mathrm{PGE}_{2}$ triggers it likely via RyR. A diagram is depicting, which we find in Figure 13. Complete comprehension of molecular mechanisms underlying secretagogues-mediated intestinal ion transports via $\mathrm{Ca}^{2+}$ signaling will enhance our knowledge of G.I. epithelial physiology and G.I. disease associated with abnormal anion secretion, such as diarrhea and constipation. 


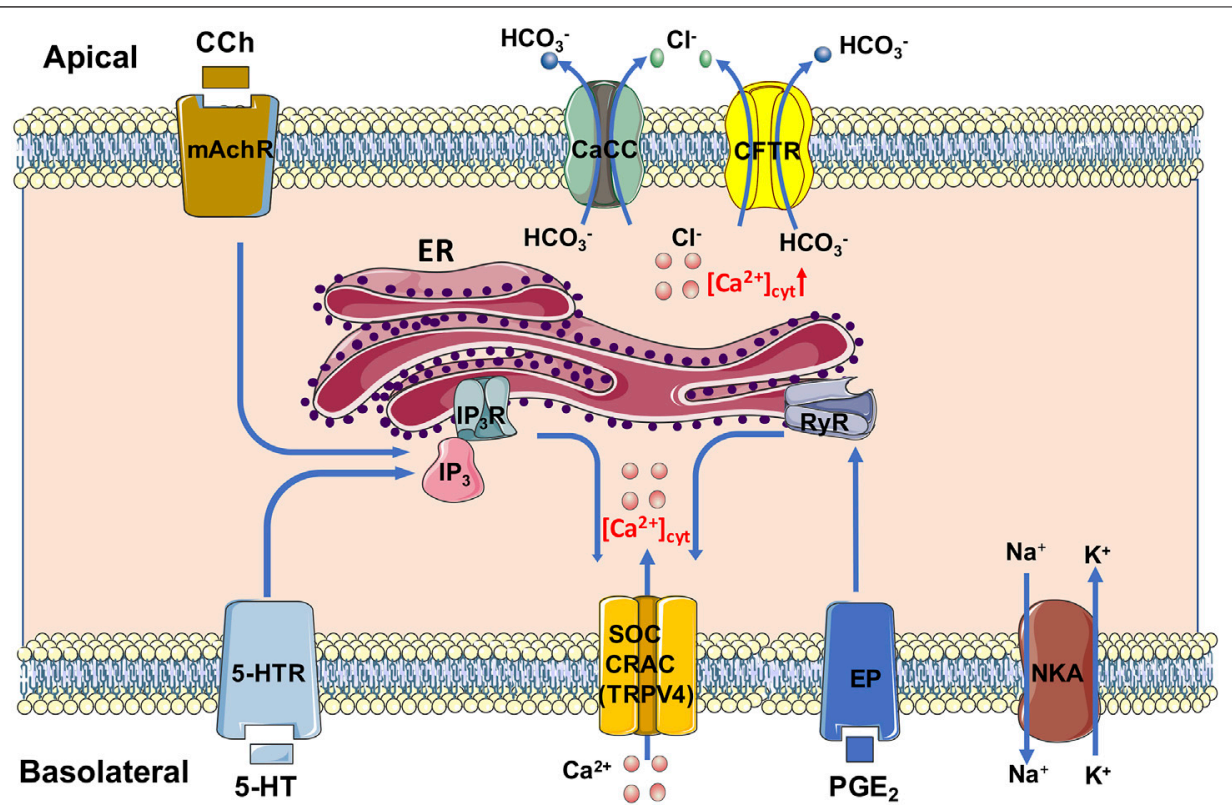

FIGURE 13 | Mechanism diagram of secretagogues mediating $\mathrm{Ca}^{2+}$ signaling in duodenal epithelial cells via TRPV4-constituted serosal SOCE mechanism. PGE 2 and 5-HT stimulate this mechanism exclusively from serosal side of the duodenum; CCh stimulates it from both sides. 5-HT and CCh trigger the ER Ca ${ }^{2+}$ release to initiate the SOCE likely via $\mathrm{IP}_{3} / \mathrm{IP}_{3} \mathrm{R}$, but $\mathrm{PGE}$ triggers it likely via RyR. CaCC, $\mathrm{Ca}^{2+}$-activated $\mathrm{Cl}^{-}$channels; CFTR, cystic fibrosis transmembrane conductance regulator; CRAC, $\mathrm{Ca}^{2+}$ release-activated $\mathrm{Ca}^{2+}$ channel; ER, endoplasmic reticulum; $\mathrm{EP}, \mathrm{PGE}_{2}$ receptor; $\mathrm{IP}_{3}$ and $\mathrm{IP}_{3} \mathrm{R}$, inositol 1,4,5-triphosphate and its receptor; $\mathrm{mAchR}$, muscarinic acetylcholine receptor; NKA, Na ${ }^{+} \mathrm{K}^{+}$ATPase; RyR, ryanodine receptor; SOC, store-operated channels; TRPV4, transient receptor potential V4; 5-HTR, 5-HT receptor.

\section{DATA AVAILABILITY STATEMENT}

The raw data supporting the conclusion of this article will be made available by the authors, without undue reservation.

\section{ETHICS STATEMENT}

The animal study was reviewed and approved by the Third Military Medical University Committee on Investigations Involving Animal Subjects.

\section{AUTHOR CONTRIBUTIONS}

HD conceived the study, designed most experiments, and finalized the manuscript. YC performed most experiments and data analysis and drafted the manuscript. FX designed, and FC, $\mathrm{KY}, \mathrm{XC}, \mathrm{HW}$, and GL helped perform some experiments. Finally, all authors reviewed the manuscript.

\section{REFERENCES}

Ashby, M. C., Camello-Almaraz, C., Gerasimenko, O. V., Petersen, O. H., and Tepikin, A. V. (2003). Long Distance Communication between Muscarinic Receptors and Ca2+ Release Channels Revealed by Carbachol Uncaging in Cell-Attached Patch Pipette. J. Biol. Chem. 278, 20860-20864. doi:10.1074/jbc.M302599200

\section{FUNDING}

This study was supported by research grants from China's National Key Research and Development Program (No. 2016YFC1302200 to H.D.) and the National Natural Science Foundation of China (No. 81873544 to H.D., and No. 81602474 to G.L.).

\section{SUPPLEMENTARY MATERIAL}

The Supplementary Material for this article can be found online at: https://www.frontiersin.org/articles/10.3389/fphar.2021.684538/ full\#supplementary-material

Supplementary Figure 1 | (A) Time courses of GSK1016790A (10 $\mu \mathrm{M})$-induced $\mathrm{sc}_{\mathrm{sc}}$ in wild-type (W.T.) and TRPV4 K.O. mice $(n=6)$, while CCh verifies that the mice tissue is alive. (B) $P \mathrm{PGE}_{2}$-evoked $I_{s c}$ after $\mathrm{HC} 067047(30 \mu \mathrm{M}, n=6)$ was added to the serosal (s) side of the TRPV4 knockout (K.O.) mice duodenum. (C) 5 -HT-evoked Isc after HC067047 ( $30 \mu \mathrm{M}, n=6)$ was added to the serosal (s) side of the TRPV4 knockout (K.O.) mice duodenum. Ctrl represents the control without drug treatment. Results are presented as mean \pm SE. NS, no significant differences vs. corresponding control by Student's unpaired, two-tailed t-test.

Balemans, D., Boeckxstaens, G. E., Talavera, K., and Wouters, M. M. (2017) Transient Receptor Potential Ion Channel Function in Sensory Transduction and Cellular Signaling Cascades Underlying Visceral Hypersensitivity. Am. J. Physiol. Gastrointest. Liver Physiol. 312, G635-G648. doi:10.1152/ ajpgi.00401.2016

Baratchi, S., Keov, P., Darby, W. G., Lai, A., Khoshmanesh, K., Thurgood, P., et al. (2019). The TRPV4 Agonist GSK1016790A Regulates the Membrane 
Expression of TRPV4 Channels. Front. Pharmacol. 10, 1-12. doi:10.3389/ fphar.2019.00006

Barrett, K. E., and Keely, S. J. (2000). Chloride Secretion by the Intestinal Epithelium: Molecular Basis and Regulatory Aspects. Annu. Rev. Physiol. 62, 535-572. doi:10.1146/annurev.physiol.62.1.535

Berridge, M. J., Bootman, M. D., and Roderick, H. L. (2003). Calcium Signalling: Dynamics, Homeostasis and Remodelling. Nat. Rev. Mol. Cell Biol. 4, 517-529. doi:10.1038/nrm1155

Bird, G. S., DeHaven, W. I., Smyth, J. T., and Putney, J. W. (2008). Methods for Studying Store-Operated Calcium Entry. Methods 46, 204-212. doi:10.1016/ j.ymeth.2008.09.009

Blackshaw, L. A., Brierley, S. M., and Hughes, P. A. (2010). TRP Channels: New Targets for Visceral Pain. Gut 59, 126-135. doi:10.1136/gut.2009.179523

Bootman, M. D., Collins, T. J., Mackenzie, L., Roderick, H. L., Berridge, M. J., and Peppiatt, C. M. (2002). 2-Aminoethoxydiphenyl Borate (2-APB) is a Reliable Blocker of Store-Operated Ca2+ Entry but an Inconsistent Inhibitor of InsP3Induced Ca2+ Release. FASEB J. 16, 1145-1150. doi:10.1096/fj.02-0037rev

Brown, D. R. (1995). Mucosal Protection Through Active Intestinal Secretion: Neural and Paracrine Modulation by 5-Hydroxytryptamine. Behav. Brain Res. 73, 193-197. doi:10.1016/0166-4328(96)00095-2

Caroppo, R., Colella, M., Colasuonno, A., DeLuisi, A., Debellis, L., Curci, S., et al. (2003). A Reassessment of the Effects of Luminal [Ca2+] on Inositol 1,4,5Trisphosphate-Induced Ca2+ Release from Internal Stores. J. Biol. Chem. 278, 39503-39508. doi:10.1074/jbc.M305823200

Carreras-Sureda, A., Pihán, P., and Hetz, C. (2018). Calcium Signaling at the Endoplasmic Reticulum: Fine-Tuning Stress Responses. Cell Calcium 70, 24-31. doi:10.1016/j.ceca.2017.08.004

Chew, C. S., Säfsten, B., and Flemström, G. (1998). Calcium Signaling in Cultured Human and Rat Duodenal Enterocytes. Am. J. Physiol. 275, G296-G304. doi:10.1152/ajpgi.1998.275.2.G296

Chung, H. K., Rathor, N., Wang, S. R., Wang, J.-Y., and Rao, J. N. (2015). RhoA Enhances Store-Operated Ca2+ Entry and Intestinal Epithelial Restitution by Interacting With TRPC1 After Wounding. Am. J. Physiol. Gastrointest. Liver Physiol. 309, G759-G767. doi:10.1152/ajpgi.00185.2015

Derler, I., Schindl, R., Fritsch, R., Heftberger, P., Riedl, M. C., Begg, M., et al. (2013). The Action of Selective CRAC Channel Blockers is Affected by the Orai Pore Geometry. Cell Calcium 53, 139-151. doi:10.1016/j.ceca.2012.11.005

Dolmetsch, R. E., and Lewis, R. S. (1994). Signaling between Intracellular Ca2+ Stores and Depletion-Activated $\mathrm{Ca} 2+$ Channels Generates [Ca2+]i Oscillations in T Lymphocytes. J. Gen. Physiol. 103, 365-388. doi:10.1085/jgp.103.3.365

Flemström, G., and Isenberg, J. I. (2001). Gastroduodenal Mucosal Alkaline Secretion and Mucosal Protection. Physiology 16, 23-28. doi:10.1152/ physiologyonline.2001.16.1.23

Gees, M., Colsoul, B., and Nilius, B. (2010). The Role of Transient Receptor Potential Cation Channels in Ca2+ Signaling. Cold Spring Harb. Perspect. Biol. 2, a003962. doi:10.1101/cshperspect.a003962

Gwozdz, T., Dutko-Gwozdz, J., Schafer, C., and Bolotina, V. M. (2012). Overexpression of Orail and STIM1 Proteins Alters Regulation of StoreOperated Ca2+ Entry by Endogenous Mediators. J. Biol. Chem. 287, 22865-22872. doi:10.1074/jbc.M112.356626

Hammerton, R., Krzeminski, K., Mays, R., Ryan, T., Wollner, D., and Nelson, W. (1991). Mechanism for Regulating Cell Surface Distribution of $\mathrm{Na}+, \mathrm{K}(+)$-ATPase in Polarized Epithelial Cells. Science 254, 847-850. doi:10.1126/science.1658934

Hoth, M., and Penner, R. (1993). Calcium Release-Activated Calcium Current in Rat Mast Cells. J. Physiol. 465, 359-386. doi:10.1113/jphysiol.1993.sp019681

Hoth, M., and Penner, R. (1992). Depletion of Intracellular Calcium Stores Activates a Calcium Current in Mast Cells. Nature 355, 353-356. doi:10.1038/355353a0

Jung, J., and Lee, M. G. (2014). Role of Calcium Signaling in Epithelial Bicarbonate Secretion. Cell Calcium 55, 376-384. doi:10.1016/j.ceca.2014.02.002

Kiela, P. R., and Ghishan, F. K. (2009). Ion Transport in the Intestine. Curr. Opin. Gastroenterol. 25, 87-91. doi:10.1097/MOG.0b013e3283260900

Kilkenny, C., Browne, W., Cuthill, I. C., Emerson, M., and Altman, D. G. (2010). Animal Research: Reporting In Vivo Experiments: The ARRIVE Guidelines. Br. J. Pharmacol. 160, 1577-1579. doi:10.1111/j.1476-5381.2010.00872.x

Lindqvist, S., Sharp, P., Johnson, I., Satoh, Y., and Williams, M. (1998). Acetylcholine-Induced Calcium Signaling Along the Rat Colonic Crypt Axis. Gastroenterology 115, 1131-1143. doi:10.1016/s0016-5085(98)70084-8
Ma, X., Cheng, K.-T., Wong, C.-O., O'Neil, R. G., Birnbaumer, L., Ambudkar, I. S., et al. (2011). Heteromeric TRPV4-C1 Channels Contribute to Store-Operated Ca2+ Entry in Vascular Endothelial Cells. Cell Calcium 50, 502-509. doi:10.1016/j.ceca.2011.08.006

MacMillan, D., Chalmers, S., Muir, T. C., and McCarron, J. G. (2005). IP3Mediated $\mathrm{Ca} 2+$ Increases do not Involve the Ryanodine Receptor, but Ryanodine Receptor Antagonists Reduce IP3-Mediated Ca2+ Increases in Guinea-Pig Colonic Smooth Muscle Cells. J. Physiol. 569, 533-544. doi:10.1113/jphysiol.2005.096529

Molnar, T., Yarishkin, O., Iuso, A., Barabas, P., Jones, B., Marc, R. E., et al. (2016). Store-Operated Calcium Entry in Muller Glia Is Controlled by Synergistic Activation of TRPC and Orai Channels. J. Neurosci. 36, 3184-3198. doi:10.1523/JNEUROSCI.4069-15.2016

Murek, M., Kopic, S., and Geibel, J. (2010). Evidence for Intestinal Chloride Secretion. Exp. Physiol. 95, 471-478. doi:10.1113/expphysiol.2009.049445

Noda, M., Yasuda, S., Okada, M., Higashida, H., Shimada, A., Iwata, N., et al. (2003). Recombinant Human Serotonin 5A Receptors Stably Expressed in C6 Glioma Cells Couple to Multiple Signal Transduction Pathways. J. Neurochem. 84, 222-232. doi:10.1046/j.1471-4159.2003.01518.x

Onodera, K., Pouokam, E., and Diener, M. (2013). STIM1-Regulated Ca2+ Influx across the Apical and the Basolateral Membrane in Colonic Epithelium. J. Membr. Biol. 246, 271-285. doi:10.1007/s00232-013-9528-9

Parekh, A. B., and Penner, R. (1997). Store Depletion and Calcium Influx. Physiol. Rev. 77, 901-930. doi:10.1152/physrev.1997.77.4.901

Putney, J. W. (2007). Recent Breakthroughs in the Molecular Mechanism of Capacitative Calcium Entry (With Thoughts on How We Got Here). Cell Calcium 42, 103-110. doi:10.1016/j.ceca.2007.01.011

Rajagopal, M., Thomas, S. V., Kathpalia, P. P., Chen, Y., and Pao, A. C. (2014). Prostaglandin E2 Induces Chloride Secretion through Crosstalk between cAMP and Calcium Signaling in Mouse Inner Medullary Collecting Duct Cells. Am. J. Physiol. Cell Physiol. 306, C263-C278. doi:10.1152/ajpcell.00381.2012

Rao, J. N., Platoshyn, O., Golovina, V. A., Liu, L., Zou, T., Marasa, B. S., et al. (2006). TRPC1 Functions as a Store-Operated $\mathrm{Ca} 2+$ Channel in Intestinal Epithelial Cells and Regulates Early Mucosal Restitution after Wounding. Am. J. Physiol. Gastrointest. Liver Physiol. 290, G782-G792. doi:10.1152/ajpgi.00441.2005

Rao, M. C., Nash, N. T., and Field, M. (1984). Differing Effects of cGMP and cAMP on Ion Transport across Flounder Intestine. Am. J. Physiol. 246, C167-C171. doi:10.1152/ajpcell.1984.246.1.C167

Raufman, J.-P., Cheng, K., and Zimniak, P. (2003). Activation of Muscarinic Receptor Signaling by Bile Acids: Physiological and Medical Implications. Dig. Dis. Sci. 48, 1431-1444. doi:10.1023/a:1024733500950

Sataloff, R. T., Johns, M. M., and Kost, K. M. (2017). "Signaling ER Store Depletion to Plasma Membrane Orai Channels," in Calcium Entry Channels in NonExcitable Cells. Editors J. A. Kozak and J. W. Putney (Boca Raton, FL: CRC Press/Taylor \& Francis).

Shibuya, I., Tanaka, K., Uezono, Y., Ueta, Y., Toyohira, Y., Yanagihara, N., et al. (2002). Prostaglandin E2 Induces Ca2+ Release from Ryanodine/CaffeineSensitive Stores in Bovine Adrenal Medullary Cells via EP1-Like Receptors. J. Neurochem. 73, 2167-2174. doi:10.1046/j.1471-4159.1999.02167.x

Takeuchi, K., and Amagase, K. (2018). Roles of Cyclooxygenase, Prostaglandin E2 and EP Receptors in Mucosal Protection and Ulcer Healing in the Gastrointestinal Tract. Curr. Pharm. Des. 24, 2002-2011. doi:10.2174/ 1381612824666180629111227

Thomas, C., and Oates, P. S. (2002). IEC-6 Cells are an Appropriate Model of Intestinal Iron Absorption in Rats. J. Nutr. 132, 680-687. doi:10.1093/jn/ 132.4.680

Thorsen, K., Drengstig, T., and Ruoff, P. (2014). Transepithelial Glucose Transport and $\mathrm{Na}+/ \mathrm{K}+$ Homeostasis in Enterocytes: An Integrative Model. Am. J. Physiol. Cell Physiol. 307, C320-C337. doi:10.1152/ajpcell.00068.2013

Tuo, B., Wen, G., Zhang, Y., Liu, X., Wang, X., Liu, X., et al. (2009). Involvement of Phosphatidylinositol 3-Kinase in cAMP- and cGMP-Induced Duodenal Epithelial CFTR Activation in Mice. Am. J. Physiol. Cell Physiol. 297, C503-C515. doi:10.1152/ajpcell.00460.2008

Vergnolle, N. (2014). TRPV4: New Therapeutic Target for Inflammatory Bowel Diseases. Biochem. Pharmacol. 89, 157-161. doi:10.1016/j.bcp.2014.01.005

Wenzl, E., Sjaastad, M. D., Weintraub, W. H., and Machen, T. E. (1989). Intracellular $\mathrm{pH}$ Regulation in IEC-6 Cells, a Cryptlike Intestinal Cell Line. Am. J. Physiol. 257, G732-G740. doi:10.1152/ajpgi.1989.257.5.g732 
Weymer, A., Huott, P., Liu, W., McRoberts, J. A., and Dharmsathaphorn, K. (1985). Chloride Secretory Mechanism Induced by Prostaglandin E1 in a Colonic Epithelial Cell Line. J. Clin. Invest. 76, 1828-1836. doi:10.1172/JCI112175

Xia, Y., Fu, Z., Hu, J., Huang, C., Paudel, O., Cai, S., et al. (2013). TRPV4 Channel Contributes to Serotonin-Induced Pulmonary Vasoconstriction and the Enhanced Vascular Reactivity in Chronic Hypoxic Pulmonary Hypertension. Am. J. Physiol. Cell Physiol. 305, C704-C715. doi:10.1152/ajpcell.00099.2013

Xie, R., Dong, X., Wong, C., Vallon, V., Tang, B., Sun, J., et al. (2014). Molecular Mechanisms of Calcium-Sensing Receptor-Mediated Calcium Signaling in the Modulation of Epithelial Ion Transport and Bicarbonate Secretion. J. Biol. Chem. 289, 34642-34653. doi:10.1074/jbc.M114.592774

Yamawaki, H., Mihara, H., Suzuki, N., Nishizono, H., Uchida, K., Watanabe, S., et al. (2014). Role of Transient Receptor Potential Vanilloid 4 Activation in Indomethacin-Induced Intestinal Damage. Am. J. Physiol. Gastrointest. Liver Physiol. 307, G33-G40. doi:10.1152/ajpgi.00105.2013

Yang, X., Wen, G., Tuo, B., Zhang, F., Wan, H., He, J., et al. (2018). Molecular Mechanisms of Calcium Signaling in the Modulation of Small Intestinal Ion Transports and Bicarbonate Secretion. Oncotarget 9, 3727-3740. doi:10.18632/ oncotarget.23197
Zhang, F., Wan, H., Chu, F., Lu, C., Chen, J., and Dong, H. (2021). Small intestinal glucose and sodium absorption through calcium-induced calcium release and store-operated Ca2+ entry mechanisms. Br. J. Pharmacol. 178 (2), 346-362. doi:10.1111/bph.15287

Zhang, F., Wan, H., Yang, X., He, J., Lu, C., Yang, S., et al. (2019). Molecular Mechanisms of Caffeine-Mediated Intestinal Epithelial Ion Transports. $\mathrm{Br}$. J. Pharmacol. 176, 1700-1716. doi:10.1111/bph.14640

Conflict of Interest: The authors declare that the research was conducted in the absence of any commercial or financial relationships that could be construed as a potential conflict of interest.

Copyright (C) 2021 Cui, Chu, Yin, Chen, Wan, Luo, Dong and Xu. This is an openaccess article distributed under the terms of the Creative Commons Attribution License (CC BY). The use, distribution or reproduction in other forums is permitted, provided the original author(s) and the copyright owner(s) are credited and that the original publication in this journal is cited, in accordance with accepted academic practice. No use, distribution or reproduction is permitted which does not comply with these terms. 